\title{
Public sphere in Latin America: A map of the historiography
}

Pablo Piccato

Columbia University

References to the "public sphere" appear increasingly often in studies of Latin American history. The category is becoming natural without a debate about the consequences of its backdoor entrance into historians' vocabulary. The purpose of this essay is to bring out its theoretical implications and to ask whether we can write a history of the public sphere in Latin America. The answer, I will argue, is a cautious yes. To prove that the field is not an invention requires care because it involves bringing together, probably against their will, historians who operate from different perspectives and on different regions, periods and themes; care is also advisable given the apparent differences between the literatures produced in Spanish and English. In arguing that there is a common ground for research in the field, the following pages will try to show that authors who work about the public sphere with ostensibly diverse methodologies share a set of questions and premises that amount, together, to a critical engagement with the theoretical model behind the category.

The scholars considered in the following pages share an interest in republican modernization, state formation and the emergence of civil societies which is implied in their use of "public sphere." Otherwise, their agenda would not seem to depart from that of a broader crowd of historians who examine the relations between society, culture and politics in Latin America, yet centering their approaches on the notion of hegemony. This essay will argue that testing the coordinates first laid out by Jürgen Habermas in The Structural Transformation of the Public Sphere, ${ }^{1}$ and more recently elaborated by scholars working on the history of the public sphere in modern western societies, can

\footnotetext{
${ }^{1}$ I am in debt with Tom Klubock, Thom Rath, Federico Sor and Mary Kay Vaughan for their comments to earlier drafts. This paper was also discussed at the Columbia University's Department of History graduatefaculty workshop and at the New School's workshop of Latin American Studies. I thank Karl Wennerlind, Herbert Sloan, Claudio Lomnitz and Paul Gootemberg for their comments.
} 
generate a productive dialogue across interpretive paradigms. The result will be the map of a province in recent Latin American historiography. As with any map, proximity will not mean identity, and while not covering the entire country, its coordinates could apply to areas beyond its margins-leaving to the user what direction to take. ${ }^{2}$

Such map is useful not only for historians. In the early twenty first century, the legacy of Latin American neo-liberal modernization, particularly the dismantling of welfare states in the wake of authoritarian regimes in the 1970s, gives a new centrality to civil society and to the political voices emerging outside the traditional channels of parties and corporative actors. During the 1990s liberalismo and democracia sin adjetivos (i.e., "political" in the narrowest sense) seemed the way of the future, while Marxism was dismissed as another brick on the Berlin wall. At the same time, authoritarian technocrats invoked science (particularly economics) to impose drastic reforms on states and economies. Yet lately electoral upsets and social movements in Argentina, Bolivia, Brazil, Ecuador, Mexico, Uruguay and Venezuela express popular dissatisfaction at the high cost of modernization from above. The entrance of new actors into the public arena (ecologist peasants, indigenous movements, women and youth NGOs, among others) challenges established explanations of political behavior, requiring more sensitive tools to study the languages of dissent and mobilization. Scholars on the left have seen in Antonio Gramsci a way to reconcile Marxism with an awareness of civil society that was sorely lacking in revolutionary persuasions of earlier decades. Juan Carlos Portantiero, for example, argues that the left can address the 1990s "crisis of

\footnotetext{
${ }^{2}$ The danger, of course, is that of creating "a Map of the Empire that was the size of the Empire and coincided point by point with it un Mapa del Imperio, que tenía el tamaño del imperio y coincidía puntualmente con él." "El rigor de la ciencia" in Jorge Luis Borges, Obras completas II 1952-1972 (Barcelona: Emecé Editores, 1996). This map will have Mexico as the apparent center. A result of my background, I hope it can be excused as a geographic convention.
} 
values" and its own lack of "mass politics" by focusing its proposals "on the "public sphere,' ... as the locus for the autonomous organization of a self-managed or cooperative society." This involves, for him, building "a new political culture not bound by the logic of the market or the logic of the state," and a critique of the increasing fragmentation and privatization of life. ${ }^{3}$

Renewed concern about civil society underlines another reason why questions about the public sphere are useful today. Since the 1962 book until his most recent work, Habermas's contribution has been guided by an inquiry about the emancipatory potential of politics - considered as a dialogue based on the use of reason and, consequently, unrestricted access and the absence of coercion. The normative implication of this definition requires a new look at the relationship between politics and culture. The task is today as urgent as ever since the electoral success of the right in the United States stems in part from a manipulation of cultural themes (labeled "morality" in exit polls) which seem to have greater impact on voters than economic rationality or the preservation of civil rights. Is it time for liberal scholars to reconsider the emphasis on culture and identity, that has presided over humanities during the last decades, and rescue the connections between meaning and social structure? Democrats and others on the left in the United States stress the need to react to Republican manipulation of culture by articulating more clearly the basic ideas about class and justice that are at the core of their political tradition since the New Deal. ${ }^{4}$

\footnotetext{
${ }^{3}$ Juan Carlos Portantiero, "Foundations of a New Politics," Report on the Americas 25, no. 5 (1991): 19. See Jürgen Habermas, The Philosophical Discourse of Modernity: Twelve Lectures, Studies in contemporary German social thought (Cambridge, Mass.: MIT Press, 1987), 37. Juan Carlos Portantiero, "Foundations of a New Politics," Report on the Americas 25, no. 5 (1991): 19; Chantal Mouffe and Ernesto Laclau, Hegemonía y estrategia socialista: Hacia una radicalización de la democracia, trans. Ernesto Laclau (Buenos Aires: Fondo de Cultura Económcia, 2004).

${ }^{4}$ For Alan Brinkley "Democrats need to turn much of their attention away from culture and back toward class." Alan Brinkley, "What's Next? The mourning period is over. Now, four simple guidelines for
} 
The goal of the following pages is to use the category of public sphere as a historiographical “detonator," to borrow Habermas's expression, rather than trying to build a new paradigm. The interdisciplinary use of the concept after the 1962 book indeed defies the "reification of lines of research into unrelated subsystems of knowledge" of contemporary academic work. ${ }^{5}$ Some historians, however, often read Habermas's public sphere as a merely descriptive, Weberian ideal type rather than a key component of a broader theory. This is understandable if we keep in mind the obvious anachronism of the term "public sphere," which was not in use until the twentieth century. ${ }^{6}$ Why not simply talk, then, about "publicity" or "public opinion"? One reason to go beyond a descriptive use is the need to engage contemporary attempts, cited above, to identify and understand the public sphere as a discrete realm of democratic life. And recognizing present needs does not preclude (quite the opposite) considering the full theoretical implications of the category. I propose that, for historians of Latin America, this specifically means bringing The Structural Transformation and subsequent ideas

becoming a majority party.," The American Prospect Online Edition, January 2004. See also forum on the election in The Nation, December 20 2004, http://www.thenation.com/issue.mhtml?i=20041220. See Jurgen Habermas, "Discourse Ethics: Notes on a Program of Philosophical Justification," in Moral consciousness and communicative action (Cambridge, Mass.: MIT Press, 1990). For the normative implications of the public sphere model, Nancy Fraser, "Rethinking the Public Sphere: A Contribution to the Critique of Actually Existing Democracy," Social Text, no. 25/26 (1990). See also Thomas A. McCarthy, The critical theory of Jürgen Habermas, 1st MIT Press paperback ed. (Cambridge, Mass.: MIT Press, 1981), chap. 1; Jürgen Habermas, Ciencia y técnica como "ideología" (Mexico City: Rei, 1993). Implicit in Habermas's idea of "communicative rationality" is "the central experience of the unconstrained, unifying, consensus-bringing force of argumentative speech." Jurgen Habermas, The Theory of Communicative Action Vol. 1 Reason and the Rationalization of Society, trans. Thomas McCarthy (Boston: Beacon Press, 1984), 10.

${ }^{5}$ Arthur Strum, "A Bibliography on the Concept of Öffentlichkeit," New German Critique 61 (1994). Habermas refers to "seminal theories," as those by Freud and Marx, that "inserted a genuinely philosophical idea like a detonator into a particular context of research" resulting in "hybrid discourses" that may be criticized from the academic establishment but could generate "new research traditions." Jurgen Habermas, "Philosophy as Stand-In and Interpreter," in Moral consciousness and communicative action, Studies in contemporary German social thought (Cambridge, Mass.: MIT Press, 1990), 15.

${ }^{6}$ The OED provides two examples of the term, both dated in 1992. See entries "Maternalize" and "Nonsensification." "Oxford English Dictionary," Oxford University Press, http://www.oed.com/. The parallel with Weber in Joan B. Landes, Women and the Public Sphere in the Age of the French Revolution (Ithaca: Cornell University Press, 1988), 10. 
about communicative action into a dialogue with the Gramscian concept of hegemony. In order to do that, it is useful to examine the multiple ways in which scholars of other regions have recast the initial formulation of the model. ${ }^{7}$ The following pages are less about theory, therefore, than about a historiographical response to a "detonator"; thus, they take "public sphere" beyond its descriptive function and examine its theoretical and methodological potential.

First, an outline of the model. Since the basic blueprint but particularly in recent usage of the category, "public sphere" refers to an unfinished historical transformation rather than a stable structure. Two processes, evolving at different rhythms, converged in the emergence of a bourgeois public sphere. The first was the gradual development of capitalist markets, requiring the reliable circulation of commodities and information. Literacy and print were central aspects of that circulation, as well as the development of national states that would regulate and guarantee exchanges. The second process was the emergence of spaces of social life, media and themes of discussion that brought together autonomous individuals who believed in their social and cultural equality. Courts, salons, newspapers, and cafes organized debates where private men and women used their taste and their reason to judge theater, literature, science and government performance. Personal reputations were the object of public critical questioning — even though the bourgeois ideal involved "bracketing" differences of status. At the convergence of both processes, the public sphere was the universally accessible conceptual space where private citizens came together to discuss matters of common interest, on the assumption that reason, the only requisite, was evenly distributed, and that their voices would have an

${ }^{7}$ Habermas himself links the public sphere with his theory of communicative action at a "fundamental" level. Jürgen Habermas, "Further Reflections on the Public Sphere," in Habermas and the Public Sphere, ed. Craig Calhoun (Cambridge, Mass.: MIT, 1997), 422, 41. Other scholars, mentioned below, have already suggested the need to confront analyses based on Gramsci and Habermas. 
impact on public opinion. In doing so, they not only represented their private interests, but established a new bridge between three areas of life: the private realms of domesticity and work, the publicity required to exchange opinions with others in civil society, and the state. Revolutions in France and the American colonies marked the politicization of the public sphere, in a process that expanded geographically throughout the nineteenth century.

Political representation has since then continued to develop, although recurrent cycles of exclusion and authoritarianism remind us that the public sphere is an ideal as much as a reality, a normative as much as a descriptive framework. During the twentieth century, the development of mass media linked to stronger states and corporate interests exercised an increasing influence on the public sphere, furthering the privatization of life and the fragmentation of civil society to the extent that the survival of the public sphere as an autonomous and unitary space seemed precarious enough, by the end of the century, to become an object of discussion for those concerned with democracy and social justice. The chronology and boundaries of the entire process are blurry: the public sphere is also the site of continuing reflection about its own rules and membership, about the links between private and public, about collective and individual identities, and about the proper interaction among politics, culture and reason. ${ }^{8}$

\footnotetext{
${ }^{8}$ Habermas initial definition is tentative and contains the diversity of issues outlined above: "The bourgeois public sphere may be conceived above all as the sphere of private people come together as a public; they soon claimed the public sphere regulated from above against the public authorities themselves, to engage them in a debate over the general rules governing relations in the basically privatized but publicly relevant sphere of commodity exchange and social labor. The medium of this political confrontation was peculiar and without historical precedent: people's public use of their reason." Jürgen Habermas, The Structural Transformation of the Public Sphere: An Inquiry into a Category of Bourgeois Society (Cambridge, Mass.: MIT, 1991), 27. See also Jurgen Habermas, "The Public Sphere: An Encyclopedia Article," New German Critique, no. 3 (1974). On the historical character of the definition, see Moishe Postone, "Political Theory and Historical Analysis," in Habermas and the public sphere, ed. Craig Calhoun, Studies in contemporary German social thought (Cambridge, Mass.: MIT Press, 1992).
} 
The research questions that scholars have derived from this narrative offer the possibility of understanding politics beyond the dichotomy of a realm of power and institutions, and another of markets and interests. Asking about the public sphere helps place civil society in the void between political society and the market opened by traditional narratives. Parties and representation are important research themes but they are less useful in situations where political legitimacy itself becomes the object of debates, and people begin asking who speaks for them and why. What are the rules to include or exclude interlocutors from such debate? As we will see, historians of Latin America are bringing those questions to the earliest phases of the region's independent life in order to explain the subdivision of polities after the end of colonial rule, in the process throwing light on the persistence of democracy in spite of inequality and violence.

What have these and other historians done to the model? Built upon the historiography available at the time, Structural Transformation does not always survive unscathed the close examination of graduate history seminars. Its empirical shortcomings have prompted research projects that test its descriptive uses, taking it as a canvass to be completed rather than as a critical engagement with existing master narratives. James Van Horn Melton, for example, looks closely at the conditions for the emergence of educated audiences, particularly the privatization of the domestic realm, in eighteenthcentury Western Europe. He criticizes Habermas for the lack of chronological precision and the influence of a "rather conventional" Marxism in his assumptions about a bourgeois identity that later historiography has found elusive. The historical materialism of the Marxist Habermas, Melton argues, cannot be reconciled with the concern in the 
Kantian Habermas about the progress of enlightenment. ${ }^{9}$ What in Structural

Transformation was a sketch, in Melton's work comes out as a detailed empirical agenda that includes the emergence of reading "publics," the development of their critical judgment (first in theater then in literature), and the rise of spaces of sociability (salons, taverns, coffeehouses). ${ }^{10}$

The most important historical qualification to the model is the recognition that, in practice, universal access to and status-bracketing within the public sphere were undermined by exclusions, mainly concerning gender and class. ${ }^{11}$ While Habermas had already noted the role of women in the literary public sphere, feminist scholars have examined gendered exclusions "from the standpoint of politics itself" —instead of unmediated effects of family and economic structures. For Joan Landes, women's exclusion was an essential aspect of the public sphere emerged of the French Revolution. The model's artificial distinction between public and private realms, she argues, reduces women's intervention in public discussions to expressing particular, domestic concerns, leaving men to voice universal interests and reason. ${ }^{12}$ Other historians of enlightened Europe respond that women were indeed included to a "high degree," and that the "public/private" dichotomy was less hermetic than authors like Landes and Sarah Maza

\footnotetext{
${ }^{9}$ James Van Horn Melton, The Rise of the Public in Enlightenment Europe, New approaches to European history (New York: Cambridge University Press, 2001), 10, 12.

${ }^{10}$ For similar agendas see E. P. Thompson, The Making of the English Working Class (New York: Random House, 1966); Richard Sennett, The Fall of Public Man (New York: Knopf, 1977).

${ }^{11}$ Geoff Eley, "Nations, Publics, and Political Cultures: Placing Habermas in the Nineteenth Century," in Culture/Power/History: A Reader in Contemporary Social Theory, ed. Nicholas B. Dirks, Geoff Eley, and Sherry B. Ortner (Princeton: Princeton University Press, 1994). The essay also in Craig J. Calhoun, Habermas and the Public Sphere, Studies in contemporary German social thought (Cambridge, Mass.: MIT Press, 1992).

${ }^{12}$ Joan B. Landes, "The Public and the Private Sphere: A Feminist Reconsideration," in Feminism, the Public and the Private, ed. Joan B. Landes (Oxford: Oxford University Press, 1998), 2, 142-43. See also Craig Calhoun, "Introduction: Habermas and the Public Sphere," in Habermas and the Public Sphere, ed. Craig Calhoun (Cambridge, Mass.: MIT, 1997), 34-35; Seyla Benhabib, "Models of Public Space: Hannah Arendt, the Liberal Tradition, and Jürgen Habermas," in Habermas and the Public Sphere, ed. Craig Calhoun (Cambridge, Mass.: MIT, 1997), 92.
} 
were willing to recognize. For Keith Michael Baker and Harold Mah, exclusion was a contingent trait of the public sphere since the normative premise of universal access included women. ${ }^{13}$ Beyond the role of women, Habermas proposes that public and private were mutually constitutive categories. The invention of a self-contained realm of domesticity allowed the bourgeois to deny his own interests and become a universal homme outside that realm. ${ }^{14}$ The feminist critique, in other words, is an inevitable part of the theory itself. In order to understand the eventual exclusion of women from public opinion, in spite of their role in court life and salons, authors like Roger Chartier and Arlette Farge incorporate cultural analysis and an interest in language into an effort to understand historical constructions of reason and irrationality as key chapters of modern political history. ${ }^{15}$ Such research on the contingent quality of basic political and cultural categories brings together phenomena usually studied separately: elite and popular sociabilities and the emergence of diverse audiences and identities; the role of print and mass media in politics, but also of gossip and other oral forms; the changing symbolic and institutional values of representation, and the circulation of diverse cultural products. The public sphere places these subjects at the intersection of economic, social, political and cultural domains isolated in traditional historical studies. ${ }^{16}$

\footnotetext{
${ }^{13}$ Harold Mah, "Phantasies of the Public Sphere: Rethinking the Habermas of Historians," Journal of Modern History 72, no. 1 (2000). I owe this reference to Samuel Moyn.

${ }^{14}$ Habermas, Structural Transformation, 27, 55; Melton, The Rise; Daniel Gordon, "Philosophy, Sociology, and Gender in the Enlightenment Conception of Public Opinion," French Historical Studies 17, no. 4 (1992): 889, 901; Keith Michael Baker, "Defining the Public Sphere in Eighteenth-Century France:

Variations on a Theme by Habermas," in Habermas and the Public Sphere, ed. Craig Calhoun (Cambridge, Mass.: MIT, 1997), 202.

${ }^{15}$ Roger Chartier, The Cultural Origins of the French Revolution (tr. Lydia G. Cochrane. Durham: Duke University Press, 1991); Arlette Farge, Subversive Words: Public Opinion in Eighteenth-Century France, trans. Rosemary Morris (University Park: The Pennsylvania State University Press, 1994). See also Landes, Women and the Public Sphere; Keith Michael Baker, Inventing the French Revolution: Essays on French Political Culture in the Eighteenth Century (Cambridge: Cambridge University Press, 1990); Sarah C. Maza, Private Lives and Public Affairs: The Causes Célèbres of Prerrevolutionary France (Berkeley: University of California Press, 1993).

${ }^{16}$ For a bibliography of the diversity of work, historical and otherwise, inspired by the model see Strum, "A Bibliography on the Concept of Öffentlichkeit." A similar census would be probably impossible today. See
} 
Public sphere in Latin American history

Historians of Latin America have not merely consumed the public sphere model, and the survey above fails to provide a useful guide into the increasingly rich historiography on the development of the public sphere in the region. Latin American history is a particularly promising arena to engage the category with other interpretive models because of the ongoing reappraisal of democracy in the region. Political change, for example, is increasingly understood as cultural change. Identity, particularly ethnic and racial identifications (largely untouched by the European debates as forms of exclusion from the public sphere), is more explicitly a terrain of debate through the vindication of indigenous rights and the return of national claims in the face of an aggressive capitalist modernization — although indigenismo and nationalism are no longer considered in opposition to globalized modernity but as specific appropriations of it. As a consequence, cultural historians have brought to the attention of the profession the need to consider the historical character and political meaning of cultures and identities. The category of the public sphere is useful in this context because it provides a sharper focus on politics than the notion of culture, and a potentially productive terrain to engage interpretive categories such as hegemony. By narrowing the discussion to specific questions about the relationship between meaning, communication and politics, the public sphere model has already proven its ability to detonate, or at least fuel, productive research agendas on culture and politics. $^{17}$

also Peter Uwe Hohendahl, "The Public Sphere: Models and Boundaries," in Habermas and the Public Sphere, ed. Craig Calhoun (Cambridge, Mass.: MIT, 1997), 108. For an example of these possibilities see Madeleine Hurd, Public Spheres, Public Mores, and Democracy: Hamburg and Stockholm, 1870-1914, Social history, popular culture, and politics in Germany (Ann Arbor: University of Michigan Press, 2000).

${ }^{17}$ A discussion of the implications of this from the point of view of Mexican history in Pablo Piccato, "Introducción: ¿Modelo para armar? Hacia un acercamiento crítico a la teoría de la esfera pública," in 
François-Xavier Guerra's work on the revolutions of independence in Spanish America, particularly Modernidad e independencias, placed the public sphere at the heart of the process of nation-building by suggesting that the birth of new nations out of Spain's American kingdoms was the product of the emergence of multiple politicized public spheres in administrative and commercial centers after the 1808 crisis. Writing and reading had a sense of political urgency that did not come, as in Europe, from the brewing of bourgeois conversations in salons and coffee shops. In Guerra's view, American subjects' need to publicly judge governance, science and reason had its origins in the eighteenth century, when the Bourbons decided to treat their American domains as colonies, rather than kingdoms of the same status as those in the Peninsula. The reforms prompted Americans to express grievances that, although modern in their publicity, were couched in the egalitarian notion of a pact between subjects and crown. The conquest-era political centrality of municipalities returned in the eighteenth century in the form of a "pactist nostalgia" behind the first wave of unrest and the emergence of local juntas. While in the past the rights of Creole and Spanish residents of American cities did not need to be defended publicly, suddenly they became the unifying theme of the politicization of public discourse and the expansion of the periodic press. ${ }^{18}$

Freedom of the press, ayuntamiento (city council) debates, and Creoles' participation in the Cádiz courts were key political events because they created pueblosor, more accurately, displaced the term's meaning from the local to the national: towns

Actores, espacios y debates en la historia de la esfera pública en la ciudad de México, ed. Cristina Sacristán and Pablo Piccato (Mexico City: Instituto Mora, 2005). See also Hispanic American Historical Review 79, no. 2 (1999); Pablo Piccato, "Conversación con los Difuntos: Una Perspectiva Mexicana ante el Debate sobre la Historia Cultural," Signos Históricos, no. 8 (2002).

${ }^{18}$ François-Xavier Guerra, Modernidad e independencias: Ensayos sobre las revoluciones hispánicas, 3a ed., Colecciones MAPFRE 1492 (Madrid, Mexico City: Editorial MAPFRE; Fondo de Cultura Económica, 2000), 117; Francois-Xavier Guerra, México: del Antiguo Régimen a la Revolución (Mexico City: Fondo de Cultura Económica, 1988). 
were now peoples. New, politicized public spheres provided American pueblos with a common set of political vocabularies and objectives that fueled political mobilization for and against independence; they reached as far as the influence of the emerging political leadership in cities like Buenos Aires, Mexico City, Bogotá, in the process bringing together diverse populations into publics, and generating a sense of nationhood and unified "popular will." If el pueblo was still a fiction constructed and represented by minorities, the debates and practices that constituted it, argued Guerra, are central objects of historical research. From a similar perspective, Carmen McEvoy characterizes the "political process of state building in Peru in the form of an intense dialogue in the cultural sphere." From the beginning, the press pondered on the value of public opinion and tried to shape it, thus shifting relations between power and writing. ${ }^{19}$ In these studies, early Latin American public spheres become more relevant foci of research than the struggling states and fragmented civil societies evolving around them.

The above description contains an emphasis that is not central in Modernidad e independencias. While Guerra explicitly used the notion of the public sphere and referred to Structural Transformation, his direct historiographical inspiration came from the expanded history of "the political" proposed by François Furet and other historians of the

${ }^{19}$ Carmen McEvoy, La utopía republicana: Ideales y realidades en la formación de la cultura política peruana, 1871-1919, 1a ed. (Lima, Perú: Pontificia Universidad Católica del Perú, 1997), 11; Carmen McEvoy, "'Seríamos excelentes vasallos y nunca ciudadanos': prensa republicana y cambio social en Lima, 1791-1822," in The Political Power of the Word: Press and Oratory in Nineteenth-Century Latin America, ed. Ivan Jaksic (London: Institute of Latin American Studies, 2002), 37. See also Richard A. Warren, Vagrants and citizens : politics and the masses in Mexico City from Colony to Republic, Latin American silhouettes (Wilmington, Del.: SR Books, 2001), 170. After independence, "Lo radicalmente nuevo es la creación de una escena pública."Guerra, Modernidad e independencias, 13, 23, 87. This parallels Benedict Anderson's claim that "the convergence of capitalism and print technology . . created the possibility of a new form of imagined community, which in its basic morphology set the stage for the modern nation," and his focus on American creole identities as early examples of this process. Benedict Anderson, Imagined Communities: Reflections on the Origin and Spread of Nationalism (New York-Londres: Verso, 1983$), 46$. Concepts like el pueblo or lo público also had a history that illustrated the incorporation of traditional and modern notions, as explored by Annick Lempérière. Annick Lempérière, "Reflexiones sobre la terminología política del liberalismo," in Construcción de la legitimidad política en México, ed. Carlos Illades, Brian Connaughton, and Sonia Pérez Toledo (Zamora: Colegio de Michoacán, 1999). 
French Revolution. Thus, while his range of interests is broad, Guerra follows Furet in focusing on the "cultural revolution that makes possible the creation of politics." ${ }^{20}$ As does Furet, Guerra deemphasizes the "bourgeois" character of the public sphere and shows little interest in probing the interactions between elites and the rest of society: economic interests and class identities were subordinated to the arrival of republican culture and the onslaught of politicization; "sociabilidades," as expressions of both public culture and traditional social links, replaced detailed socioeconomic analysis. ${ }^{21}$ The revolutions of independence, in Guerra's view, were not great socioeconomic transformations yet heralded values eventually embraced by all strata. Thus, asking about the emergence of a bourgeois public sphere in terms of "social class" was less useful than, following Tocqueville, asking about the coming together of elites as a "cultural class. $" 22$

A specific kind of cultural analysis defines this narrative, thus laying out the different views of the public sphere in Latin American history. Guerra looked at the

\footnotetext{
${ }^{20}$ Guerra, Modernidad e independencias, 30. See François Furet, Penser la Révolution française (Paris: Gallimard, 1978). For Palti, Guerra's use of Habermas lacked a "strong" critique of the public sphere model and failed to recognize Raymond Kosseleck's work as a necessary antecedent. Furet and Cochin were decisive in Guerra's work to strengthen that critique, without embracing "las teorías multiculturalistas 'posmodernas." Elías José Palti, "Guerra y Habermas: ilusiones y realidad de la esfera pública Latinoamericana," in Conceptualizar lo que se ve: François-Xavier Guerra historiador, homenaje, ed. Erika Pani and Alicia Salmerón (Mexico City: Instituto Mora, 2004), 466.

${ }^{21}$ See Dena Goodman, "Public Sphere and Private Life: Toward a Synthesis of Current Historiographical Approaches to the Old Regime," History and Theory 31, no. 1 (1992): 8, 12. Guerra's explicit rejection of Habermas's Marxism in Guerra, Modernidad e independencias, 86n, 87, 14. For studies inspired by Guerra's insights and a closer connection to local contexts see Francois-Xavier Guerra and Annick Lempérière, Los espacios públicos en Iberoamérica: Ambigüedades y problemas: Siglos XVIII-XIX (México: Fondo de Cultura Económica, 1999). For the public sphere as part of the politicization of new national societies, Pilar González Bernaldo, "Sociabilidad, espacio urbano y politización en la ciudad de Buenos Aires (1820-1852)," in La vida política en la Argentina del siglo XIX: armas, votos y voces, ed. Hilda Sabato and Alberto Rodolfo Lettieri (Buenos Aires: Fondo de Cultura Económica, 2003), 199. ${ }^{22}$ Guerra, Modernidad e independencias, 12, 101. Such characterization of the socioeconomic impact and causes of the revolutions of independence is challenged in John Tutino, From Insurrection to Revolution in Mexico: Social Bases of Agrarian Violence, 1750-1940 (Princeton: Princeton University Press, 1988); Eric Van Young, The Other Rebellion: Popular Violence, Ideology, and the Mexican Struggle for Independence, 1810-1821 (Stanford, Calif.: Stanford University Press, 2001).
} 
intersection of "culture," which he defined by its autonomy from the socioeconomic realm, and politics, and concluded that modern elite sociabilities were the key to the Spanish American experience. With the public sphere, he claimed, emerged a group of "men of the word and the pen" who created public opinion. ${ }^{23}$ Literate, secular, enlightened, exposed to French influence through travel and reading, these men were at the forefront of "that cultural mutation which is modernity." ${ }^{.24}$ Disconnected from class relations and economic grievances or interests, Guerra's modernization worked its way from elites "in a descending way to other social groups. ${ }^{25}$ Modernity was, in Guerra's perspective, coherent, socially restrictive, and unequivocal in the European direction of its "mutations."

Looking at the vocabulary of republicanism, historians of the public sphere in Spanish America explore, in the words of Carmen McEvoy, a "cultural texture much more rich and complex than that provided by the classic liberal interpretation."26 Republicanism itself is "the process of interaction between a vocabulary, associated to a specific ethos, and the sphere of public opinion," incarnated in men "of the pen and the sword" like Juan Espinosa, author of a 1855 republican lexicon edited by McEvoy. Sociability here becomes a sharper category, that involves the social conditions for the

\footnotetext{
${ }^{23}$ Guerra, Modernidad e independencias, 17, 91, 234. For others, the Habermasian focus on "a new, autonomous, free, and sovereign public" implies a marked alternative from Furet's Tocquevillian emphasis on associations and modes of sociability as the base for a modern public opinion. Chartier, Cultural Origins, 16-17.

${ }^{24}$ Guerra, Modernidad e independencias, 52.

${ }^{25}$ Guerra, Modernidad e independencias, 99. Guerra's emphasis on culture fits well with older visions of "Latin American culture" as something clearly identifiable; for Edmundo O'Gorman, this common identity meant that the influence of the United States is negligible in the emergence of a Latin American political culture. Edmundo O'Gorman, "Hegel y el moderno panamericanismo," Letras de México 2, no. 8 (1939). See Charles Hale, "Edmundo O'Gorman y la historia nacional," Signos Históricos 2, no. 3 (2000): 17, 24. Absent is a problematization of neocolonialism as an informal and subordinate mode of entering modernity. Tulio Halperín Donghi, The Contemporary History of Latin America, trans. John Charles Chasteen, Latin America in translation/en traducción/em tradução (Durham, N.C.: Duke University Press, 1993).

${ }^{26}$ McEvoy, La utopía republicana, 11.
} 
production of fighting words: cultural markets, patronage by bureaucrats and other urban neighbors, and the work of printers as key cultural entrepreneurs. ${ }^{27}$ The results go beyond discourse. State building after independence, from this angle, was part of a larger civilizing process in which el pueblo went "from a rhetorical community to a political community."28

The focus on the language of politics in recent intellectual histories of early Latin American polities results in a critical reassessment of the teleology of modernization and a less optimistic account of a transition from old structures to partial modernity. According to Rafael Rojas, while new audiences emerged as a consequence of enlightened discussions since 1808, political discourse continued to be generated "within viceroyal bodies and according to the corporative imaginary." Hence, those audiences were not true expressions of modern citizenship. If the revolution of independence had any meaning as a "social movement," argues Rojas, it was because of "the building of a modern public sphere" — paradoxically based on "secret societies, local conspiracies, armed bands, opinion groups, provincial assemblies and parliamentary factions" in Cádiz. ${ }^{29}$ Rojas echoes Guerra's view of elites as creators and incarnation of el pueblo yet argues that independence cannot be characterized as a democratic "cultural mutation" but as a paradoxical renewal of monarchism through republicanism. Classical republicanism had been in the minds of modernizing elites, of course, but, claims Rojas, it was a largely traditional view of monarchical order that opened the public sphere. ${ }^{30}$ For José Antonio

\footnotetext{
${ }^{27}$ McEvoy, "Seríamos excelentes vasallos." Similar insights, to be examined below, in Angel Rama, The Lettered City, trans. John Charles Chasteen (Durham: Duke University Press, 1996).

${ }^{28}$ McEvoy, "Seríamos excelentes vasallos."

${ }^{29}$ Rafael Rojas, La escritura de la independencia: El surgimiento de la opinión pública en México, 1 st ed. (Mexico City: Taurus--Centro de Investigación y Docencia Económicas, 2003), 17, 34, 35, 62.

${ }^{30}$ Rojas, La escritura, 35. See also Fernando Escalante, Ciudadanos imaginarios: Memorial de los afanes y desventuras de la virtud y apología del vicio triunfante en la República Mexicana: Tratado de Moral Pública (Mexico: Colegio de México, 1993). For recent studies of monarchist sentiment in Mexico see
} 
Aguilar, this stress on the republican tradition, incarnated in local liberties and virtù with deeper roots than Enlightenment sociabilities, constitutes a critique of national narratives centered on liberalism and its "epidermic" anti-monarchism. ${ }^{31}$ Republicanism was less about democratic representation than about the pragmatic means to achieve balance between new and old powers. ${ }^{32}$

This new interest in republicanism in Latin America involves an attempt to redraw disciplinary boundaries and vindicate the autonomy of the intellectual realm. For Elías José Palti, intellectual history provides a much-needed updating for a Latin American historiography that had remained at the margins of the linguistic turn. ${ }^{33}$ Palti locates public opinion at the center of a study of the connections between ideological conflict, public debates and vocabularies, and political legitimacy. Latin American public opinions expressed the hope of national unity but were also the product of fractious polities, yet understanding political discourse requires going beyond the analysis of

Erika Pani, Para mexicanizar el Segundo Imperio: el imaginario político de los imperialistas, 1. ed. (México, D.F.: Colegio de México Centro de Estudios Históricos : Instituto de Investigaciones Dr. José María Luis Mora, 2001); Elías José Palti, ed., La política del disenso: La "polémica en torno al monarquismo" (México, 1848-1850)... y las aporías del liberalismo (Mexico City: Fondo de Cultura Económica, 1998). If in the end the new nations rejected liberal monarchism, explains Rojas, it was because of the revolutionary logic of insurgency and the consequent loyalist response, but not because of any inherently democratic feature of the new public sphere. Rojas, La escritura, 49.

31 José Antonio Aguilar, "Dos conceptos de república," in El republicanismo en hispanoamérica: Ensayos de historia intelectual y política, ed. José Antonio Aguilar and Rafael Rojas (Mexico City: Centro de Investigación y Docencia ; Fondo de Cultura Económica, 2002), 63. See José Antonio Aguilar and Rafael Rojas, eds., El republicanismo en hispanoamérica: Ensayos de historia intelectual y politica, 1a ed., Sección de obras de historia (Mexico City: Centro de Investigación y Docencia ; Fondo de Cultura Económica, 2002), 7; McEvoy, "Seríamos excelentes vasallos," 43.

${ }^{32}$ For the "tradición republicana" as the center of a long-term political history of Mexico that stresses local and corporative representation over democracy and equality, see Alicia Hernández Chávez, La tradición republicana del buen gobierno, 1. ed., Sección de obras de historia (México, D.F.: El Colegio de México : Fideicomiso Historia de las Américas : Fondo de Cultura Económica, 1993); Antonio Annino, "Ciudadanía versus gobernabilidad republicana en México: Los orígenes de un dilema," in Ciudadanía política y formación de las naciones: Perspectivas históricas de América Latina, ed. Hilda Sábato (Mexico City: Fce, 1999). For a similar perspective (the intellectual history a la Cambridge, invoked by Aguilar), see Gordon, "Philosophy, Sociology, and Gender," 883-85, 88, 91.

${ }^{33}$ Elías José Palti, "Las polémicas en el liberalismo argentino: Sobre virtud, republicanismo y lenguaje," in El republicanismo en hispanoamérica: Ensayos de historia intelectual y política, ed. José Antonio Aguilar and Rafael Rojas (Mexico City: Centro de Investigación y Docencia ; Fondo de Cultura Económica, 2002), 167. 
discourse as expression of factional conflict and probing the conditions of possibility of enunciations. This is no longer about finding the right label (liberal, conservative, modern, traditional, republican, monarchical, etc.) but about apprehending the moment of "generalized politics" that followed independence, when even the basic principles of political order could be debated..$^{34}$

Palti's proposes a reconsideration of the arch of nineteenth-century political history. Mexican public opinion underwent a transformation from a predominantly oral “judicial public opinion" that worked as the tribunal of opinion, adjudicating debate through the accumulation of arguments rather than seeking an ultimate truth, to a more unified and autonomous "strategic" or "proselytistic" public opinion: explicitly partisan, more coherent and able, later in the nineteenth century, to finally build a stable legitimacy with a deliberate use of the "technology of writing." ${ }^{35}$ Methodologically, this implies greater attention to the heuristic value of conflict and rhetoric. The judicial public opinion did not operate on the assumption of unanimity, Palti argues, but in an agonistic mode of constant defense and attack. Early ideologues despised political parties, which were supposed to discipline opinion, because reason had to be unencumbered by loyalties in order to judge the performance of government, however nasty the results; honesty and autonomy were more important than programmatic coherence. Power intervened in

\footnotetext{
${ }^{34}$ Elías José Palti, La invención de una legitimidad: Razón y retórica en el pensamiento mexicano del siglo XIX (Un estudio sobre las formas del discurso político) (Mexico City: Fondo de Cultura Económica, 2005).

${ }^{35}$ Elías José Palti, "La transformación del liberalismo mexicano en el siglo XIX: Del modelo jurídico de la opinión pública al modelo estratégico de la sociedad civil," in Actores, espacios y debates en la historia de la esfera pública en la ciudad de México, ed. Pablo Piccato and Cristina Sacristán (Mexico City: Instituto Mora, 2005). See also chapters in Carlos Illades and Kuri Ariel Rodríguez, eds., Instituciones y ciudad. Ocho estudios históricos sobre la ciudad de México (Mexico City: FP-SONES-Uníos, 2000); Brian Connaughton, Carlos Illades, and Sonia Pérez Toledo, eds., La construcción de la legitimidad política en México (Mexico City: El Colegio de Michoacán-Universidad Autónoma Metropolitana-Universidad Nacional Autónoma de México-El Colegio de México, 1999). On France and public opinion see Baker, Inventing the French Revolution; Mona Ozouf, "Le concept d'opinion publique au XVIIIème siècle," in L'Homme régénéré. Essais sur la Révolution française (Paris: Gallimard, 1989); Farge, Subversive Words.
} 
public opinion later in the century by manipulating and creating news and subjects, and stressing social organization over autonomy. ${ }^{36}$ Such analyses throw new light on a nineteenth-century press that national histories had simplified to the confrontation between conservatives and liberals. ${ }^{37}$ Rhetoric becomes more than an aesthetic aspect of language: for Jorge Myers, the history of public opinion in Argentina is that of the Buenos Aires elite's efforts to legitimize its rule and offer an alternative to the sacred authority monopolized by the pulpit. In the process, those elites hypostatized reason and

\footnotetext{
${ }^{36}$ Palti, La invención de una legitimidad, 301; Elías José Palti, "La Sociedad Filarmónica del Pito: Ópera, prensa y política en la República Restaurada (México, 1867-1876)" (paper presented at the Construcciones impresas. Diarios, periódicos y revistas en la formación de los estados nacionales en América Latina y Estados Unidos (1820-1920), Buenos Aires, May 2002); Palti, "La transformación del liberalismo." Guerra, however, noted the importance of discussion to reach the "verdad social" in a process that links private and public realms and contradictory interests. Unanimity, as in Palti's scheme, is only reached later. Guerra, Modernidad e independencias, 270-71, 73. For similar processes in Argentina, Palti, "Las polémicas." The "judicial" mode of public opinion provides a useful framework for the recent interest in the history of rhetoric from its colonial, mostly religious uses, to the nineteenth-century uses of oratory in the building of nationalism. Ivan Jaksic, The Political Power of the Word: Press and Oratory in Nineteenth-Century Latin America (London: Institute of Latin American Studies, 2002).

${ }^{37}$ See also Elías José Palti, "Introducción," in La política del disenso: La "polémica en torno al monarquismo" (México, 1848-1850)... y las aporías del liberalismo, ed. Elías José Palti (Mexico City: Fondo de Cultura Económica, 1998); Elías José Palti, "La Sociedad Filarmónica del Pito. Ópera, prensa y política en la República Restaurada (México, 1867-1976)," Historia Mexicana 52, no. 4 (2003); Elías José Palti, "Los diarios y el sistema político mexicano en tiempos de la República Restaurada (1867-1876)," in Construcciones impresas. Panfletos, diarios y revistas en la formación de los estados nacionales en América Latina, 1820-1920, ed. Paula Alonso (Buenos Aires: FCE, 2004). On the increasing interest in the history of the press in Latin America see Paula Alonso, ed., Construcciones impresas: Panfletos, diarios y revistas en la formación de los estados nacionales en América Latina, 1820-1920 (Buenos Aires: FCE, 2004); Jaksic, The Political Power of the Word; Florence Toussaint Alcaraz, Escenario de la prensa en el Porfiriato, 1. ed. ed. (Mexico City: Fundacion Manuel Buendía-Universidad de Colima, 1989); Miguel Angel Castro and Universidad Nacional Autónoma de México. Seminario de Bibliografía Mexicana del Siglo XIX., eds., Tipos y caracteres : la prensa mexicana (1822-1855); memoria del coloquio celebrado los días 23, 24 y 25 septiembre de 1998, 1. ed. (México: Instituto de Investigaciones Bibliográficas Seminario de Bibliografía Mexicana del Siglo XIX Universidad Nacional Autónoma de México, 2001); Martha Celis de la Cruz, "El empresario Vicente García Torres (1811-1894)," in Tipos y caracteres : la prensa mexicana (1822-1855) ; memoria del coloquio celebrado los días 23, 24 y 25 septiembre de 1998, ed. Miguel Angel Castro (México: Instituto de Investigaciones Bibliográficas Seminario de Bibliografía Mexicana del Siglo XIX Universidad Nacional Autónoma de México, 2001); Moises Ochoa Campos, Reseña histórica del periodismo mexicano (Mexico: Porrua, 1968); María Cruz Seoane, Oratoria y periodismo en España del siglo XIX (Valencia: Fundación Juan March, 1977); María del Carmen Ruiz Castañeda et al., El periodismo en México: 450 años de historia, $<1$. ed.> ed. (Mexico City: Editorial Tradición, 1974); Moises Guzman Pérez, "Practiques de sociabilité et de lecture en Nouvelle-Espagne: L'evêche de Michoacán (1870-1810)," Bulletin de L'Institut Pierre Renouvin, no. 17 (2003).
} 
made it a militant actor in the confrontation against barbarianism and the enemies of "las luces. $" 38$

Modernity, particularly in Guerra's works, can become a limiting canvass that, for example, tends to leave aside a key pre-independence field of debate, source of rhetorical devises and sponsor of the expansion of printed media: religion. Religious education, social practices and associations, deeply rooted in the colonial period, remained essential in political and intellectual life throughout the nineteenth century — and they did not necessarily exclude democratic contents. Colonial debates and political disputes centered on theology (such as the confrontation between bishop of Puebla Juan de Palafox y Mendoza and the Jesuits in the seventeenth century) suggest the existence of a public sphere of sorts before independence. ${ }^{39}$ Further research on colonial-era debates and political dissent is probably a matter of expanding students' ability to break codes (theology, Latin, canonical law, architecture, ritual practices) that national-era historians are reluctant to take on. ${ }^{40}$ The open-ended political analysis encouraged by the public

\footnotetext{
${ }^{38}$ Jorge Myers, "Las paradojas de la opinión: El discurso político rivadaviano y sus dos polos: El "gobierno de las luces" y "la opinión pública, reina del mundo"," in La vida política en la Argentina del siglo XIX: armas, votos y voces, ed. Hilda Sabato and Alberto Rodolfo Lettieri (México ; Estados Unidos de América ; Buenos Aires: Fondo de Cultura Económica, 2003), 80, 88, 93; José Elías Palti, "Recent studies on the emergence of a Public sphere in Latin America," Latin American Research Review 36, no. 2 (2001). On the political role of reason see McCarthy, The critical theory of Jürgen Habermas.

${ }^{39}$ See Silvia Arrom, "Una nueva sociabilidad femenina: Las señoras de la caridad de San Vicente de Paul, 1863-1910" (paper presented at the V Seminario Internacional Sobre la Experiencia Institucional de la Ciudad de México: las Sociabilidades en la ciudad de México del siglo XIX a la Revolución,, Mexico City, 23 de junio de 2005 2005); Guzman Pérez, "Practiques de sociabilité"; Carlos A. Forment, Democracy in Latin America, 1760-1900, Morality and society (Chicago: University of Chicago Press, 2003); Carlos Herrejón Peredo, "Sermones y discursos del primer imperio," in Construcción de la legitimidad política en México, ed. Carlos Illades, Brian Connaughton, and Sonia Pérez Toledo (Zamora: Colegio de Michoacán, 1999). After independence, the influence of Rome became strong enough to become hegemonic only late in the nineteenth century. On Palafox and the Jesuits Charles E. P. Simmons, "Palafox and His Critics: Reappraising a Controversy," Hispanic American Historical Review 46, no. 4 (1966).

${ }^{40}$ See for example William B. Taylor, Magistrates of the Sacred: Priests and Parishioners in EighteenthCentury Mexico (Stanford, Calif.: Stanford University Press, 1996); Nora E. Jaffary, False Mystics: Deviant Orthodoxy in Colonial Mexico, Engendering Latin America (Lincoln: University of Nebraska Press, 2004).
} 
sphere model might turn out be useful to explore the diversity and hierarchies of baroque political cultures.

\section{¿Español o inglés?}

Palti, Guerra, Myers and other researchers are indeed "transforming scholarly approaches to nineteenth-century Latin American political and intellectual history." ${ }^{, 41}$ Yet there does not seem to be a strong dialogue between the practitioners of cultural history in the U.S and historians of the esfera pública, a conversation that would point to common research questions or an open confrontation of interpretive paradigms. It would be myopic to dismiss Guerra and others because their political affiliations depart from those of "progressive scholars." ${ }^{42}$ A sounder, frequently cited reason is the teleological implication of Guerra's emphasis on a dichotomy of tradition against modernity, yet this is not the case for all the studies cited above ${ }^{43}$ Fundamentally, I believe, the reluctance of English-speaking cultural historians to talk about the public sphere stems from divergent views about the causality of cultural and political phenomena. Too easily U.S. Latin Americanists read "public sphere" as equivalent to "Enlightenment"- just another name for the same old liberal thematic. After all, Guerra wrote a history of elites that passed as

\footnotetext{
${ }^{41}$ Palti, "Recent studies."

${ }^{42}$ The exclusive focus on "progressive scholars," without a reference to Guerra, in Steve Stern, "Between Tragedy and Promise: The Politics of Writing Latin American History in the Late Twentieth Century," in Reclaiming the political in Latin American history : essays from the North, ed. G. M. Joseph (Durham, NC: Duke University Press, 2001), 41. Guerra's books are not mentioned in that volume and his influential México: del antiguo régimen a la revolución still awaits for an English translator. It is not easy to document the absence of a dialogue but the lack of works bringing together the authors mentioned in these pages might be evidence of it.

${ }^{43}$ Palti, "Recent studies"; Luis Fernando Granados, "Calpultin decimonónicos: Aspectos nahuas de la cultura política de la ciudad de México," in Actores, espacios y debates en la historia de la esfera pública en la ciudad de México, ed. Pablo Piccato and Cristina Sacristán (Mexico City: Instituto Mora, 2005). For a critique of the teleology in the model of the public sphere see Francois-Xavier Guerra and Annick Lempérière, "Introducción," in Los espacios públicos en Iberoamérica: Ambigüedades y problemas: Siglos XVIII-XIX, ed. Francois-Xavier Guerra and Annick Lempérière (México: Fondo de Cultura Económica, 1999), 9. The criticism does not apply to Habermas's view of modern rationalism and its teleological implications. Habermas, Theory of Communicative Action.
} 
el pueblo but remained elites, while Rojas and Aguilar emphasize republicanism over democracy and other forms of representation. The risks are clear: skewing the traditional centrality of political parties in national narratives, as Palti proposes, adds nuance but may sacrifice an organizing guide to link institutions and socioeconomic interests. ${ }^{44}$

Try as they might to avoid it, however, these authors' engagement with the public sphere forces them to address social mediations beyond the world of ideas. The results are mixed, since gender, class and other markers of difference are tangential to their research agenda. ${ }^{45}$ Rojas, for example, uses "marginality" to explain the ambiguous class character of insurgent pamphlet writers in Mexico. The poorly dressed authors who straddled high ideological discourse and plebeian audiences belonged in traditional sociabilities characterized by patronage, the old face-to-face communication of pulquerias, and the everyday closeness to "the vile populace"; highly educated, these pamphleteers nevertheless mocked the upper classes, thus defining their political role in terms of resentment. ${ }^{46}$ Intellectual histories of the public sphere à la Rojas are less likely to look for social actors, political parties and representative practices (which in his view were slow to be adopted in Mexican politics anyway), and more likely to stick to the

\footnotetext{
${ }^{44}$ For analyses of the complexities of those links see Peter Guardino, "Barbarism or republican law?: Guerrero's peasants and national politics, 1820-1846," Hispanic American Historical Review 75, no. 2 (1995); Ariel De la Fuente, Children of Facundo: Caudillo and Gaucho Insurgency During the Argentine State-Formation Process (La Rioja, 1853-1870) (Durham N.C.: Duke University Press, 2000).

${ }^{45}$ For similar criticisms of the public sphere model from the perspective of intellectual history see David A. Bell, "The "Public Sphere," the State, and the World of Law in Eighteenth-Century France," French Historical Studies 17, no. 4 (1992): 615-916; Gordon, "Philosophy, Sociology, and Gender," 889. Aguilar faults deterministic "explicaciones que privilegian aspectos culturales." Aguilar, "El republicanismo," 83.

${ }^{46}$ Rojas, La escritura, 181, 70, 85. The marginality of those writers is debatable considering the enormous amount of publications they produced and the canonical stature of at least one of them, José Joaquín Fernández de Lizardi. For a useful examination of Lizardi's central place in Mexican ideas about citizenship and identity, see Robert McKee Irwin, Mexican Masculinities (Minneapolis: University of Minnesota Press, 2003).
} 
world of the literate public and its ability to open a "public space for the writing of a new imaginary. $" 47$

There is nothing intrinsic to the Habermasian model that would prevent it from linking questions about publicity and language with questions about gender, class, ethnicity, and about the power of markets and institutions to shape identities. The articulation of private interests in public was, after all, part of the historical development of the public sphere, as was the circulation of cultural products. ${ }^{48} \mathrm{We}$ can find the complexity of the public/private divide in McEvoy's interest in politicians' ethics and in Palti's and other authors' view of judicial public opinion as the judge of characters and reputations. Further studies of the notion of honor could contribute in this direction. ${ }^{49}$ The interesting question about causality is not whether private interests were the basis of political debates, but what were the specific historical conditions (mostly notions of gender) that turned those interests into rational and national utterances.

The lack of a strong dialogue between political historiographies of Latin America in Spanish and English might therefore be an effect of editorial decisions (translations

\footnotetext{
${ }^{47}$ Rojas, La escritura, 45,33 . Who read and how the social context of audiences created diverse readings is a question asked by another growing group of scholars. See Chartier, Cultural Origins; Iain MacCalman, Radical Underworld: Prophets, Revolutionaries and Pornographers in London, 1795-1840 (London: Clarendon, 1992); Michael Warner, The letters of the Republic: Publication and the Public Sphere in Eighteenth-Century America (Cambridge, Mass.: Harvard University Press, 1990); Melton, The Rise; Pablo Piccato, "Jurados de imprenta en México: El honor en la construcción de la esfera pública," in Construcciones impresas. Panfletos, diarios y revistas en la formación de los estados nacionales en América Latina, 1820-1920, ed. Paula Alonso (Buenos Aires: FCE, 2004).

${ }^{48}$ Habermas, Structural Transformation, 18.

${ }^{49}$ Palti, "Recent studies"; Palti, "Las polémicas." Looking at honor disputes, I would disagree with the thesis that reputation was no longer the concern of Mexican public in the late nineteenth century. Pablo Piccato, "Jurados de imprenta en México: El honor en la construcción de la esfera pública," in Construcciones impresas. Panfletos, diarios y revistas en la formación de los estados nacionales en América Latina, 1820-1920, ed. Paula Alonso (Buenos Aires: FCE, 2004). See also for Peru Sarah C. Chambers, From Subjects to Citizens: Honor, Gender and Politics in Arequipa, Peru, 1780-1854 (University Park, PA: Pennsylvania State University, 1999), 92. In his critique of Maza's and Habermas's work, Bell notes the importance of subsidized press and courts of law as venues to express the same critical discourse that a strict Habermasian model would locate only in salons and independent newspapers. Bell, "The "Public Sphere," the State, and the World," 919, 26, 28, 37.
} 
matter) rather than a symptom of fundamental differences. Several areas of research witness the development of common questions of relevance for cultural historians and those interested in the public sphere. Two seem particularly dynamic: the colonial legacy of the public sphere and the local, particularly urban dimension of its emergence.

Even if politicized and closely linked to revolution-era European vocabularies, the public sphere that emerged in Spanish America around 1808 was structured by colonial institutions and interests. I mentioned above the possibilities of religion as a theme to be analyzed from this perspective. "Colonial" here refers to several forces that transcended the severing of political ties: the notion of an original autonomy of American kingdoms and corporations, the reciprocal obligations between king and subjects that evolved into popular sovereignty after abdication, and the intense urban political life that only came to be registered in print late in the eighteenth century. ${ }^{50}$ These insights are outlined in Víctor Uribe's synthesis “The Birth of the Public Sphere during the Age of Revolution." If the Latin American public sphere was always politicized, that does not mean it appeared around the time of independence. Instead, argues Uribe, echoing William Taylor, it came to be during an "age of revolution" marked not only by 1789 but also by rebellions and conspiracies in Saint Domingue, Brazil, the Alto Peru and Colombia. Unlike in Europe, the stable historical development of markets and states was less important here than the social and political ferment resulting in new sovereign realms and diversifying trade links. Ayuntamientos, universities and other sites of learned debate, such as scientific

\footnotetext{
${ }^{50}$ Besides Guerra's works, see Annick Lempérière, Entre dieu et le roi, la république: Mexico, XVIe-XIXe siècle, Histoire ; 65 (Paris: Belles lettres, 2004); Ann Twinam, Public Lives, Private Secrets: Gender, Honor, Sexuality, and Illegitimacy in Colonial Spanish America (Stanford, Calif.: Stanford University Press, 1999); Taylor, Magistrates; John L. Phelan, The people and the king. The Comunero Revolution in Colombia (Madison: University of Wisconsin Press, 1978); Palti, "Recent studies"; Antonio Annino, "El Jano bifronte: Los pueblos y los orígenes del liberalismo en México," in Crisis, Reforma y Revolución: México: Historias de Fin de Siglo, ed. Leticia Reina and Elisa Servín (México, D.F.: Taurus : CONACULTA-INAH, 2002), 209.
} 
expeditions and economic societies, laid the foundation for a cultural class composed mainly of lawyers and letrados who went on to have important roles in the insurgent and loyalist bands in the $1810 \mathrm{~s} .{ }^{51}$ (Priests could also be added to the list, at least in Mexico.) Beyond those elites, recent explorations of Andean rebellions during this age have uncovered the strong ethnic component of revolutionary political engagement, republicanism and communal democracies. ${ }^{52}$

Another decisive insight of histories of the public sphere in Latin America has been the recognition of the need to bring back politics into an urban scale. This means first that national and regional narratives can be studied in reference to capitalino elites' ability (in their role of military and political leaders but also as "public opinion") to mobilize other actors and to incorporate their claims into the "cultural revolution" of liberal republicanism. In Buenos Aires, Mexico City and Lima, public spheres were tied to routes of commodities and information, and to administrative life. Ventilating national conflicts in smaller cities was common from the early republic, as illustrated by the

\footnotetext{
${ }^{51}$ Victor Uribe Uran, "The Birth of a Public Sphere in Latin America during the Age of Revolution," Comparative Studies in Society and History 42, no. 2 (2000): 425-27, 37, 39. This is the first systematic treatment of the public sphere model in Latin America published in English. On the age of revolution see Uribe, "Introduction," in Victor Uribe Uran, State and Society in Spanish America during the Age of Revolution, Latin American silhouettes (Wilmington, Del.: Scholarly Resources, 2001). For a fundamental statement in this direction William B. Taylor, "Between Global Process and Local Knowledge: An Inquiry into Early Latin American Social History, 1500-1900," in Reliving the Past: The Worlds of Social History, ed. Olivier Zunz (Chapel Hill: University of North Carolina Press, 1985). But see Eric Van Young, "Conclusions," in State and Society in Spanish America during the Age of Revolution, ed. Victor Uribe Uran (Wilmington, Del.: Scholarly Resources, 2001), 223, 36. A similar search for the seventeenth-century roots of the English public sphere in Steve Pincus, "'Coffee Politicians Does Create": Coffeehouses and Restoration Political Culture," The Journal of Modern History 67, no. 4 (1995). On trade and politization, Paul Gootenberg, Imagining Development: Economic Ideas in Peru's "Fictitious Prosperity" of Guano, 1840-1880 (Berkeley, Calif.: University of California Press, 1993).

${ }^{52}$ See Mark Thurner, "'Republicanos' and 'La Comunidad de Peruanos': Unimagined Political Communities in Postcolonial Andean Peru," Journal of Latin American Studies 27, no. 2 (1995); Sinclair Thomson, We Alone Will Rule: Native Andean Politics in the Age of Insurgency, Living in Latin America (Madison: University of Wisconsin Press, 2002); Sergio Serulnikov, "Disputed Images of Colonialism: Spanish Rule and Indian Subversion in Northern Potosi, 1777-1780," Hispanic American Historical Review 76, no. 2 (1996).
} 
widespread printing of political pamphlets and the participation of urban crowds in disputes about national sovereignty. ${ }^{53}$

We have in Ángel Rama's The Lettered City a paradigmatic account of Latin American cities' intellectual and spatial evolution. For Rama the letrados-educated writers, often journalists or lawyers but also bureaucrats and academics — benefited during the colonial period from the separation between the baroque language of the state and the verbal freedom of popular culture. The separation between these two realms became problematic as education and the growth of cities (both in size and within letrados' mental landscape) forced them to understand the relation between language and class. Rather than the sequence orality $\rightarrow$ technologies of writing proposed by Palti and implicit in other narratives of modernization, Rama argued that letrados" "writing market" came first from politicians' demand for speeches and laws and from a dynamic cultural marketplace around newspapers. With the modernization of late-nineteenth century cities, mass politics, education and urban transformations expanded the lettered city into a scale that broke with the social and intellectual structure of the original colonial urban design, pushing intellectuals to combine the literary appropriation of popular languages with the energy of propaganda. ${ }^{54}$ Thus, and in spite of their own

${ }^{53}$ Warren, "Vagrants," 3, 19, 17; Malcom Deas, Del poder y la gramática: y otros ensayos sobre historia, política y literatura colombianas (Bogotá: Tercer Mundo Editores, 1993), 179, 87; Guzman Pérez, "Practiques de sociabilité." See the seminal Tulio Halperín Donghi, Revolución y guerra. Formación de una élite dirigente en la Argentina criolla (México: Siglo Veintiuno, 1979).

${ }^{54}$ By the twentieth century, wrote Rama, "the lettered city had itself been transformed . . . from a handful of elite letrados designing government policies in their own image, into a socially more heterogeneous group that retained a vision of itself as a cultural aristocracy but incorporated powerful democratizing crosscurrents." Rama, The Lettered City, 112, 42-43, 88-89, 02-03, 04, 13. On transculturation, see "Los procesos de transculturación en la narrativa latinoamericana" (1974) in Angel Rama, La novela en América Latina: Panoramas 1920-1980 (Montevideo: Fundación Angel Rama Universidad Veracruzana, 1986). The dictatorships of the 1970s, that forced Rama into exile, were an example of the manipulation of public opinion made possible by mass media, but also, a source of new literary creativity, as in earlier phases of the Latin American lettered city. "La censura como conciencia artística" (1979) in Angel Rama, La riesgosa navegación del escritor exiliado (Montevideo: Arca, 1993), 233-48. Although I have found no evidence of any exchange between Habermas and Rama (Habermas's book was published in Spanish in 1981, two years before Rama's death in exile) it is clear their syntheses shared a concern about the future of 
prejudices, letrados supported educational reform and succeeded, through literary

nationalism, in creating an "informed citizenry" and "a discourse on the definition, formation, and collective values of the nation." ${ }^{95}$

Scholars, some of them explicitly engaged with Habermas, have enlarged the cast of city characters, particularly during the twentieth century. According to Diane Davis, for example, twentieth-century urban designers and administrators knew how the built environment could create mass audiences. In Mexico City, commerce in downtown areas was a key factor in the evolution of residential projects and in the politicization of chilangos as urban consumers. ${ }^{56}$ In downtown plazas (the semiotic center of Rama's ciudad letrada) but also in restaurants, bars, chicherias, cantinas, pulperías and theaters, cities hosted multiple forms of oral and manuscript communication that judged private reputations and, therefore, citizen's ability to be part of public opinion. Family and

\footnotetext{
democracy. There is no reference to Habermas in Rama's diary. He had taken up German lessons in 1974, to be able to read Walter Benjamin in his language, so we can imagine an eventual coincidence. Angel Rama and Rosario Peyrou, Diario, 1974-1983 (Montevideo, Uruguay: Ediciones Trilce, 2001), 34. ${ }^{55}$ Rama, The Lettered City, 47, 66. See also José Luis Romero, Latinoamérica: las ciudades y las ideas (Buenos Aires: Siglo XXI, 1976); James R. Scobie, Buenos Aries, From Plaza to Suburb, 1870-1910 (New York: Oxford University Press, 1974). On thinking the nation, Claudio Lomnitz-Adler, Deep Mexico, Silent Mexico: An Anthropology of Nationalism, Public worlds ; v. 9 (Minneapolis: University of Minnesota Press, 2001); Antonio Annino and François-Xavier Guerra, Inventando la nación: Iberoamérica siglo XIX, 1. ed. (Mexico City: Fondo de Cultura Económica, 2003). Writing was also necessarily a means to exclude the plebe through aesthetic criteria. See Graciela Montaldo, Ficciones culturales y fábulas de identidad en América Latina (Rosario, Argentina: Beatriz Viterbo Editora, 1999), 29.

${ }^{56}$ Diane E. Davis, "El rumbo de la esfera pública: Influencias locales, nacionales e internacionales en la urbanización del centro de la ciudad de México, 1910-1950," in Actores, espacios y debates en la historia de la esfera pública en la ciudad de México, ed. Cristina Sacristán and Pablo Piccato (Mexico City: Instituto Mora, 2005). See in that same volume chapters by Georg Leidenberger and Luis Fernando Granados for other explorations of the urban dimension of the public sphere, and Ariel Rodríguez Kuri, "Desabasto, hambre y respuesta política, 1915," in Instituciones y ciudad. Ocho estudios históricos sobre la ciudad de México, ed. Carlos Illades and Ariel Rodríguez Kuri (Mexico City: FP-SONES-Uníos, 2000).
} 
clientelistic networks, friendship but also enmity operated in this urban scale. ${ }^{57}$ The public sphere in these works is not only a physical space, but it is also one. ${ }^{58}$

Living in town was constitutive of private interests: the rights of a town dweller were codified in ways that preceded and paralleled the rights of citizen of the nation. In this regard the "bourgeois" component of the public sphere refers in Latin America less to class identity than to the quality of burgher.$^{59}$ Vecindad (literally, stable residence in a pueblo or city) was central in the colonial articulation of political rights and in postindependence societies where ethnic classifications no longer had legal strength. Vecindad did not refer only to residents but also integrated migrants by considering honor as a personal good earned through actions and the judgment of public opinion. Not surprisingly, when sovereignty reverted to los pueblos with independence, local institutions and physical spaces became key for citizenship: vecinos had to have an

\footnotetext{
${ }^{57}$ See Alicia del Aguila Peralta, Callejones y mansiones: Espacios de opinión pública y redes sociales y políticias en la Lima del 900 (Lima: Pontificia Universidad Católica del Perú, 1997); Palti, "Recent studies"; Guerra and Lempérière, Los espacios públicos; Lomnitz-Adler, Deep Mexico, Silent Mexico, 148. For an interest in orality see recent works out of the Universidad Iberoamericana department of history and the journal Historia y Grafia. These patterns were also present in rural society. See John Charles Chasteen, "Violence for Show: Knife Duelling on a Nineteenth-Century Cattle Frontier," in The Problem of Order in Changing Societies: Essays on Crime and Policing in Argentina and Uruguay, 1750-1940, ed. Lyman L. Johnson (Albuquerque: University of New Mexico Press, 1990), and other works in that volume; Pablo Piccato, "'El populacho" y la opinión pública: Debates y motines sobre la deuda inglesa en 1884," in Poder y legitimidad en México, Siglo XIX: Instituciones y cultura política, ed. Brian Connaughton (Mexico City: Universidad Autónoma Metropolitana-Miguel Angel Porrúa, 2003).

${ }^{58}$ Mah warns about "spacialization" of the public sphere. Mah, "Phantasies ." This critique applies to Guerra and Lempérière, Los espacios públicos, but most recent studies do not seem to be too concerned about a dichotomy between spatial and conceptual "spheres."

${ }^{59}$ Guerra and Lempérière, "Introducción," 7. For a critique of the French bourgeoisie as exclusive model, see Geoff Eley, "The British Model and the German Road: Rethinking the Course of German History Before 1914," in The Peculiarities of German History: Bourgeois Society and Politics in NineteenthCentury Germany, ed. David Blackbourn and Geoff Eley (Oxford: Oxford University Press, 1984), 52, 75 76, 79; David Blackbourn, "The German Bourgeoisie: An Introduction," in The German Bourgeoisie. Essays on the social history of the German middle class from the late eighteenth to the early twentieth century, ed. David Blackbourn and ed Richard J. Evans (London and New York: 1992), 2. See further discussion in Piccato, "Introducción." For the ambiguity between "bourgeois" and "civil" in German see Jean L. Cohen and Andrew Arato, Civil society and political theory, Studies in contemporary German social thought (Cambridge, Mass.: MIT Press, 1992), viii.
} 
"honest way of living"-a requirement in Mexican constitutions that allowed local notables to adjudicate the right to vote. ${ }^{60}$

Citizenship remained problematic after written constitutions, and in the last fifteen years it has been one of the central themes of Latin American historiography. Encouraged by new evidence about vecindad and by the transition to democracy, authors have explored the contradictions of post-colonial regimes where political rights were supposed to be universal, yet access to political influence continued to be restricted. ${ }^{61}$ As their knowledge of nineteenth-century political practices and discourses sharpened, researchers have tackled mechanisms of political representation and exclusion, including and beyond elections, to explain the success or failure of regimes. Patronage had been the traditional argument to prove that democracy in Latin America was not so democratic and that little could be gained by reading constitutions. But, as research began to erode the images of dual, hierarchical societies, studies of electoral practices established the complex, locally determined interactions between "traditional" means of political action and the "modern" practices of the ballot box. ${ }^{62}$ Elections, however, could take research

\footnotetext{
${ }^{60}$ Tamar Herzog, Defining Nations: Immigrants and Citizens in Early Modern Spain and Spanish America (New Haven: Yale University Press, 2003), 2, 6; Annino, "El Jano bifronte"; Antonio Annino, "Cádiz y la revolución territorial de los pueblos mexicanos 1812-1821," in Historia de las elecciones en Iberoamérica, siglo XIX: De la formación del espacio político nacional, ed. Antonio Annino (Buenos Aires: FCE, 1995); Rojas, La escritura, 46. For examples of the continuity and importance of local sovereignties and communities in Mexico, see Andrés Lira, Comunidades indígenas frente a la ciudad de México: Tenochtitlan y Tlatelolco, sus pueblos y barrios, 1812-1919 (Mexico City: El Colegio de México, 1995); Granados, "Calpultin decimonónicos."

${ }^{61}$ See for example Peter F. Guardino, Peasants, Politics, and the Formation of Mexico's National State: Guerrero, 1800-1857 (Stanford, Calif.: Stanford University Press, 1996); Charles Walker, Smoldering ashes: Cuzco and the creation of Republican Peru, 1780-1840, Latin America otherwise (Durham, NC: Duke University Press, 1999); Hilda Sábato, Ciudadanía política y formación de las naciones: Perspectivas históricas de América Latina (Mexico City: Fondo de Cultura Económica, 1999); Escalante, Ciudadanos imaginarios. For a contemporary perspective on the public sphere as a qualitative index of democracy, Phillip Oxhorn, "When Democracy isn't all that Democratic: Social Exclusion and the Limits of the Public Sphere in Latin America," in The North-South Agenda (Miami: North-South Center, University of Miami, 2001).

${ }^{62}$ See Antonio Annino, ed., Historia de las elecciones en Iberoamérica, siglo XIX: De la formación del espacio político nacional (Buenos Aires: FCE, 1995); Hilda Sábato, Alberto Rodolfo Lettieri, and Programa de Estudios de Historia Económica y Social Americana., eds., La vida política en la Argentina
} 
only so far, as evidence suggested that most of the action was happening around, before and after the actual vote.

It is not surprising, then, that the same historians who worked on elections have turned their attention toward civil society as a more comprehensive focus of enquiry. In her introduction to a volume suggestively entitled La vida politica en la Argentina del siglo XIX: Armas, votos y voces, Hilda Sabato refers to this "thematic explosion" brought about by Guerra and other political historians, in order to challenge nation and state as the natural points of departure for the study of politics, hence taking a closer look at "the relations between civil society and the political system.." ${ }^{93}$ In The Many and the Few, the key of those relations, and the most important factor to explain electoral outcomes, are civil associations. ${ }^{64}$ Based on a detailed contextualization of street-level practices in nineteenth-century Buenos Aires, Sabato sees the public sphere as a direct representation of specific social actors. Yet relation is not unidirectional: mechanisms of representation and the political identity of collective actors may change as a result of discussions in the public sphere, and it can fragment into multiple public spheres, although political society (elections and the state) ultimately remains the driving force behind the emergence of civil society. Thus, although Sabato was one of the first scholars to incorporate the public

del siglo XIX: armas, votos y voces, 1a ed., Sección de obras de historia (México ; Estados Unidos de América ; Buenos Aires: Fondo de Cultura Económica, 2003). A review of the literature that points to a "wider, multilayered view of political citizenship" in Hilda Sabato, "On Political Citizenship in NineteenthCentury Latin America," American Historical Review 106, no. 4 (2001). For a critique from a Latin American perspective of Habermas's lack of interest on representative practices, Guerra and Lempérière, "Introducción," 9-10. See on patronage see, f. ex., Richard Graham, Patronage and politics in Nineteenth Century Brazil (Stanford: Stanford University Press, 1990); Adrian A. Bantjes, As if Jesus Walked on Earth: Cardenismo, Sonora, and the Mexican Revolution (Wilmington, Del.: SR Books, 1998). ${ }^{63}$ Hilda Sabato, "Introducción: La vida política argentina: miradas históricas sobre el siglo XIX," in La vida politica en la Argentina del siglo XIX: Armas, votos y voces, ed. Hilda Sabato and Alberto Rodolfo Lettieri (Mexico City: Fondo de Cultura Económica, 2003), 10, 11.

${ }^{64}$ Hilda Sábato, The Many and the Few: Political Participation in Republican Buenos Aires (Stanford, Calif.: Stanford University Press, 2001). First published in Spanish as Hilda Sábato, La politica en las calles : entre el voto y la movilización: Buenos Aires, 1862-1880 (Buenos Aires: Editorial Sudamericana, 1998). For the historiographical context of this work see Palti, "Recent studies." 
sphere into historical research in Latin America, she now cautiously characterizes the category as "controversial," too closely connected to the European bourgeoisie and, in Latin America, to the state-building period of the second half of the nineteenth century. ${ }^{65}$

Are civil society and the state the inevitable reference and ultimate rationale of the public sphere? Habermas and other authors have emphasized "communicative practice," the dialogical building of meanings and voices, as a way to bridge the conceptual gap between civil society, the market, and politics. Examining the public sphere becomes in that perspective a central operation in the history of civil societyparticularly as we try to understand the transition from totalitarianism to democracy, and to the mass media-dominated politics of contemporary Western societies. ${ }^{66}$ Sabato's use of "civil society" as the realm of voluntary associations autonomous from the state gives priority to preexisting socioeconomic identities. But identities are changed by debate itself, by the contents and rules of actors' intervention in the public sphere. Postindependence civic associations defined themselves in multiple ways: ethnically, ideologically, spatially, by trade. Class identity was not merely a condition for associative life, but the point of intersection of labor relations, individual and "intimate" interests, and the state as regulator of work - thus simultaneously referring to domestic, local,

\footnotetext{
${ }^{65}$ Sábato, The Many and the Few, 9 and ff. Ideas about the public sphere and its fragmentation are also presented in Sabato, "On Political Citizenship." She acknowledges that the notion, along with civil society and sociability, "have rendered visible a new set of questions and problems." Sabato, "On Political Citizenship"; Sábato, The Many and the Few, 10. For an earlier formulation Hilda Sábato, "Citizenship, Political Participation and the Formation of the Public Sphere in Buenos Aires 1850s-1880s," Past and Present, no. 136 (1992). A divided public sphere, a common Latin American variation from the Habermas model, as we will see below, postulated in Oskar Negt and Alexander Kluge, Public Sphere and Experience: Toward an Analysis of the Bourgeois and Proletarian Public Sphere, Theory and history of literature ; v. 85 (Minneapolis: University of Minnesota Press, 1993).

${ }^{66}$ Habermas, "Further Reflections," 452-55; Cohen and Arato, Civil society and political theory. Habermas uses the term "lifeworld," rather than culture, to refer to the horizon of meaning that makes possible communicative action. See Habermas, Theory of Communicative Action, 43, 70; Habermas, The Philosophical Discourse, 37-43.
} 
regional and national levels of identification. ${ }^{67}$ A public sphere-centered examination of civil society, in other words, avoids simplistic notions about the autonomy of the political or the subordination of culture to social relations, framing a historical interpretation of economic interests as they turn into political mobilization and debates. ${ }^{68}$

One example of the potential rewards of this agenda is Carlos Forment's history of Latin American democracy. Based on an extensive database of civic associations and printed media in Mexico and Peru, Forment lays out the public sphere, along with political, economic and civil societies, as one of the "public terrains" on which Latin American democracy flourished during the nineteenth century. In his view, the public sphere makes possible communication between the other realms of democracy; if, for example, civil society is to have an impact on economic processes and decision-making it can only be through the public sphere. ${ }^{69}$ Dividing the terrain of the public sphere into "Literate," "Oral" and "Visual" subfields, ${ }^{70}$ Forment builds a counter-intuitive history of democracy that fuses a Tocquevillian large narrative with a close look at "socio-moral practices." The key thematic connection between these two dimensions, according to Forment, is that between passion, Catholicism, and civil society. The hypothesis could be stronger if supported by a close reading, that other historians will surely attempt, of the

\footnotetext{
${ }^{67}$ See a proposal to look at class in similar terms in Claudio Lomnitz, Exits from the Labyrinth: Culture and Ideology in the Mexican National Space (Berkeley: University of California Press, 1992). See following section on the coincidences between this program and a Gramscian study of ideology and "subject positions."

${ }^{68}$ For a reflection on culture, ethnic identity, economic grievances, morality as "sites" for political discussion see Van Young, The Other Rebellion, 16-17, 90. Questions about economic and political behavior emerged as one of the centers of the debate about new cultural history of Mexico in History New Cultural, Hispanic American Historical Review 79:2 (May 1999), edited by Susan Deans-Smith and Gilbert M. Joseph. See a useful analysis of the debates about civil society in Margaret R. Somers, "Narrating and Naturalizing Civil Society and Citizenship Theory: The Place of Political Culture and the Public Sphere," Sociological Theory 13, no. 3 (1995).

${ }^{69}$ Forment, Democracy in Latin America, 18, 18n. This is similar to Sabato's view of the role of the public sphere between state and civil society, and departs only in terms of emphasis from a public-sphere centered theory of civil society as in Cohen and Arato, Civil society and political theory.

${ }^{70}$ Forment, Democracy in Latin America, 22.
} 
self-referential, narrowly "political" debates that occupied much of the nineteenth century public sphere in those countries. Forment, after all, seeks to upset intellectual and political historians' election- and elite- centered narratives, to the point of declaring municipal politics and elections of small importance. Such dismissal of the established narratives of politics (found also in Palti's La invención de una legitimidad) can be justified by Forment's breadth of the comparison (Mexico and Peru in the first installment, Argentina and Cuba to follow). The magnitude of the sample, the strictures of the taxonomy and his provocative stance toward political history's received truths compel Forment to postulate, like Sabato, the existence of fragmented public spheres. ${ }^{71}$

Fragmentation is a recurrent argument against a public sphere that Habermas postulated, above all, as unitary. The notion is invoked in such different ways (from geographical partition to fragmentation of discourses) that it deserves a serious reconsideration as the seemingly furthest limit of new research. ${ }^{72}$ Although besieged by politics, geography and class, Latin American public spheres continued to think of themselves as unitary, coterminous with the nation, and those who met in the public sphere felt entitled to use rational languages as part of a universalistic drive for coherence and clarity. Recent insights about local practices reveal commonalities behind the fragmented polities that emerged from the breakdown of the empire- such as vecindadsuggesting that the grand ideological design of "national" politics and the tightly-knit

\footnotetext{
${ }^{71}$ Forment, Democracy in Latin America, xiv. He does not incorporate the church and some local religious associations into his analysis. See, f. ex., Robert D. Putnam, Bowling Alone: The Collapse and Revival of American Community (New York: Simon \& Schuster, 2000). Ayuntamientos, he claims, were "moribund" before independence, in spite of the evidence harnessed by other authors and the overwhelming interest about them in the nineteenth-century press Forment, Democracy in Latin America, 46, 441, 21. See also Forment, Democracy in Latin America, , 24-25 (on little stories and grand narratives and fragmented public sphere), 121 (on the fragmented morality of economic society), 338 (on Civic Catholicism).

${ }^{72}$ See for example James C. Scott, Domination and the Arts of Resistance: Hidden Transcripts (New Haven: Yale University Press, 1990).
} 
identities and narrow interests of "local" politics combined in creative ways. ${ }^{73}$ Sarah Chambers, for example, examines the connections between city and national politics, through "political debates [that] were often more raucous" than the idealized meeting of rational subjects of the enlightened model. Such debates took place in diverse social spaces (from upper class salons to plebeian bars), that nevertheless linked print and orality, and were the point of reference for political mobilization and public rituals. ${ }^{74}$ Claudio Lomnitz shows how regional and class fragmentation in Mexico made the development of a national public sphere a difficult undertaking, easily hijacked by intellectuals who claimed to speak for the popular will. His methodological response (ethnographic and historical research on regions, their overlapping cultural fields and their complex relationship with "the center") accounts for the cultural and political implications of Mexican spatial segmentation..$^{75}$

\section{Public sphere or hegemony?}

Forment and Chambers suggest that the public sphere can detonate a dialogue between the works discussed above and historians of Latin America who, coming from a Gramscian interest in civil society and hegemony, have also examined the relationship between culture and politics. The works of historians like Mary Kay Vaughan and

\footnotetext{
${ }^{73}$ Examples of the value of this research are Guardino, Peasants, Politics; Guy P. C. Thomson and David G. LaFrance, Patriotism, Politics, and Popular Liberalism in Nineteenth-Century Mexico: Juan Francisco Lucas and the Puebla Sierra, Latin American silhouettes (Wilmington, Del.: Scholarly Resources, 1999). See also Guerra and Lempérière, "Introducción," 13, 14; Jennie Purnell, Popular Movements and State Formation in Revolutionary Mexico: The Agraristas and Cristeros of Michoacán (Durham: Duke University Press, 1999). For local studies of modernity and the emergence of the public sphere, Guerra and Lempérière, Los espacios públicos.

${ }^{74}$ Chambers, From Subjects to Citizens, 10-11, 244; Taylor, "Between Global Process."

${ }^{75}$ Lomnitz examines political rituals, such as presidential campaigns, which look like the opposite of free discussion but bridge exclusions and fragmentation. Lomnitz-Adler, Deep Mexico, Silent Mexico, chap. 7, p. 150. See also Lomnitz, Exits from the Labyrinth: Culture and Ideology in the Mexican National Space. Rituals receive a close examination in William H. Cheryl English Martin Beezley and eds William E. French, Rituals of Rule, Rituals of Resistance (Wilmington: Scholarly Resources, 1994).
} 
Florencia Mallon, for example, question citizenship and pay close attention to political language. Vaughan's work on education in Mexico coincides with public sphere-centered analyses in the emphasis on Mexican political culture's greater inclusiveness after independence, and in the relevance of interactions between local and national actors established through a new political language. Mallon's study of the intervention of popular actors in conflicts "over power and meaning" similarly stresses dialogues that shape national "metanarratives of political history."76 These dialogues also establish the position of actors beyond mere economic relations. Language is historically relevant because relations between interlocutors are potentially mutable — at least when there is an open-ended exchange about political and social relations. In this perspective, the limit to the possibilities of dialogue (the inverted mirror of fragmentation) is power. An overarching divide of political actors as divided between dominant and subordinated makes power the ultimate ratio of meaning. This results in a vacuum between state and civil society that actors can only fill with pragmatic negotiations through mediators or heroic, counterhegemonic discourses. ${ }^{77}$

Engaging these authors from the perspective of a history of the public sphere requires, first, a critical reconsideration of subalternity. Mallon and Vaughan and other

\footnotetext{
76 "Struggles over citizenship and liberty, attempts to expand and make real the universal promises of nationalism and democracy .... When subalterns engaged in conflict over power and meaning, they helped define the contours of what was possible in the making of nation-states." Florencia Mallon, Peasant and Nation: The Making of Postcolonial Mexico and Peru (Princeton: Princeton University Press, 1995), 9. See also Mary Kay Vaughan, Cultural Politics in Revolution: Teachers, Peasants, and Schools in Mexico, 1930-1940 (Tucson: University of Arizona Press, 1997).

77 "Cultural brokers" like teachers can be particularly important in their ability to produce and translate political discourse. See Christopher R. Boyer, Becoming Campesinos: Politics, Identity, and Agrarian Struggle in Postrevolutionary Michoacan, 1920-1935 (Stanford, Calif.: Stanford University Press, 2003), 28; Jeffrey Rubin, Decentering the Regime: Ethnicity, Radicalism, and Democracy in Juchitán, Mexico (Durham: Duke University Press, 1997). For a review of the questions facing cultural historians see Stern, "Between Tragedy," 41; Somers, "Narrating and Naturalizing Civil Society and Citizenship Theory: The Place of Political Culture and the Public Sphere"; Gilbert M. Joseph and Daniel Nugent, eds., Everyday Forms of State Formation: Revolution and the Negotiation of Rule in Modern Mexico (Durham: Duke University Press, 1994).
} 
cultural historians have been accused of embracing an eclectic set of theoretical positions.

But a look at a common reference, the Subaltern Studies Group in India, provides a few suggestive leads beyond those charges. The Group's early project involved a critique of elitism in Indian historiography and an effort to rethink nationalism. While the Indian bourgeoisie, Ranajit Guha argued, failed to speak for the nation, the autonomous politics of "the people" (synonymous with "subaltern classes") raised the need to critically understand the interaction between civil society and state in post-independence politics. ${ }^{78}$ Yet the Group's recent turn toward Foucaldian study of discourse made it harder to document the notion of a true autonomy of popular politics, and took the initial critique of elitism into a more radical direction, against Enlightenment and post-Enlightenment thinking. ${ }^{79}$ For Dipesh Chakrabarty, the fragmentation of "realms of sovereignty" contradicts the hypothesis of unity (national or cultural). Ironically, the incommensurability of political languages implied in this insight does not operate when, as progressive intellectuals, Chakrabarty and others emphasize the dialogical character of their intellectual project—intended simultaneously to give voice to the subaltern, teach

\footnotetext{
${ }^{78}$ Ranajit Guha, "On Some Aspects of the Historiography of Colonial India," in Mapping subaltern studies and the postcolonial, ed. Vinayak Chaturvedi (London: Verso, 2000), 1, 3, 5, 7. See also Partha Chartterjee, "The Nation and Its Peasants," in Mapping subaltern studies and the postcolonial, ed. Vinayak Chaturvedi (London: Verso, 2000), 9-11; Ranajit Guha, A Subaltern studies reader, 1986-1995 (Minneapolis ; London: University of Minnesota Press, 1997), xiv-xv, xvii, xix; Mallon, Peasant and Nation: The Making of Postcolonial Mexico and Peru, 3. For critiques of hegemony and subordination see Alan Knight, "Subalterns, Signifiers, And Statistics: Perspectives on Mexican Historiography," Latin American Research Review 37, no. 2 (2002); Forment, Democracy in Latin America, 438-39; Stephen Haber, "Anything Goes: Mexico's 'New" Cultural History," Hispanic American Historical Review 79, no. 2 (1999); Claudio Lomnitz, "Barbarians at the Gate? A Few Remarks on the Politics of the 'New Cultural History of Mexico'," Hispanic American Historical Review 79, no. 2 (1999); Alan Knight, "Subalterns, Signifiers, and Statistics: Perspectives on Mexican Historiography," Latin American Research Review 37, no. 2 (2002).

${ }^{79}$ On the critique of Enlightenment and the influence of Foucault see Sumit Sarkar, "Orientalism Revisited: Saidian Frameworks in the Writing of Modern Indian History," in Mapping subaltern studies and the postcolonial, ed. Vinayak Chaturvedi (London: Verso, 2000), 240-41, 44. The turn to text noted in Florencia Mallon, "The Promise and Dilemma of Subaltern Studies: Perspectives from Latin American History," American Historical Review 99, no. 5 (1994): 1513.
} 
them how to be democratic, and learn politics from them ${ }^{80}$ As others have noted, the shifting political project and the nebulous meaning of "Enlightenment" beg for a more explicit engagement with studies of the constitution of peoples, nations and citizenshipa set of questions that coincides, almost point by point, with the agenda of historians of the public sphere in Latin America. ${ }^{81}$

As a central category for subaltern studies and recent cultural history of Latin America, hegemony has been a privileged way for historians to bring these questions together, as it simultaneously addresses the discursive character of the "continuous process" of producing meaning that is politics, and the inequality of power and antagonistic relationship between subordinated and dominant. It is a delicate balance: class identities are not fixed but relational and not necessarily anchored on relations of production; the role of coercion remains a necessary reference, yet the line between it and consent is always fine.$^{82}$ In the Mexican "national space," for example, Lomnitz refers to hegemony as something that is not exercised by a specific class, but only exists in cultural spaces structured by class domination. Those spaces, that begin at the local level but whose upper-most level is always national, are defined by common meanings enforced by class power-yet a class identity that is experienced, and studied, through the intertwined references of the circulation of cultural products, space, work, family, local and national ideologies ${ }^{83}$ Ernesto Laclau and Chantal Mouffe's influential

\footnotetext{
${ }^{80}$ Dipesh Chakrabarty, "Radical Histories and Question of Enlightenment Rationalism: Some Recent Critiques of Subaltern Studies," in Mapping subaltern studies and the postcolonial, ed. Vinayak Chaturvedi (London: Verso, 2000), 274-76. See also Chartterjee, "On Some Aspects," 10; Mallon, "The Promise and Dilemma," 1497.

${ }^{81}$ Chartterjee, "On Some Aspects," 13; David Arnold, "Gramsci and Peasant Subalternity in India," in Mapping subaltern studies and the postcolonial, ed. Vinayak Chaturvedi (London: Verso, 2000), 41-42.

${ }^{82}$ See Mouffe and Laclau, Hegemonía y estrategia, 125, 33, 44-45, 88.

${ }^{83}$ Claudio Lomnitz-Adler, Las salidas del laberinto: Cultura e ideologia en el espacio nacional mexicano, 1. ed. ed. (Mexico City: J. Moritz : Planeta, 1995), 43, 44.
} 
formulation of hegemony criticizes essentialized class identities and incorporates a Foucaldian interest in the dispersion of "discursive formations." Yet they maintain the centrality of power (or class enforcement) in the production of meaning, shifting the key for the interpretation of debates staged in the public sphere beyond it, onto social relations that cannot be examined as discourse.$^{84}$ From a perspective theoretically anchored on the notion of hegemony and a Gramscian view of language and power, Habermas is characterized by his "idealist" assumptions about the possibility of communication without coercion, thus making him unable to examine power relations. ${ }^{85}$

How does this alternative between enforcement and dialogue as objects of analysis translate into historiographical practice? In studies like those of Vaughan, the stress is on negotiation, specifically around education, as a central mechanism of Mexican politics. Even if actors speak different political languages (the traditional, democratic building of consent at local levels and the rational, universalistic citizenship) they can find ways to translate an engage in common enterprises. Mallon's study of patriotic resistance in the nineteenth century is one such example: Indians and city liberals found a common theme that served each others' interests in fighting French intervention. "Negotiation" is useful as a descriptive tool but does not touch the problem of the fine line between consent and coercion. Mallon's analysis reveals the different meanings of liberal doctrine, not only between national leadership and peasants but also across regions characterized by different kinds of caudillo leadership. Integrative struggles for the land coexisted with exclusionary legalism in an uneasy dialogue. Her work and that of other cultural historians is more concerned about establishing the

\footnotetext{
${ }^{84}$ Mouffe and Laclau, Hegemonía y estrategia, 151.

${ }^{85}$ Peter Ives, Gramsci's Politics of Language: Engaging the Bakhtin Circle and the Frankfurt School (Toronto: University of Toronto Press, 2004). Ives, however, makes no reference to Structural Transformation in his discussion of Habermas.
} 
material conditions and contexts for dialogues than that of other (intellectual) historians

of the public sphere. Yet the result seems to be, at least in Mallon's Peasant and Nation, a return to a diálogo de sordos where liberal state indigenismo is a caricature of the past it celebrates, and contemporary Indians just want to be left alone-leaving a reader who has just finished Palti or Forment's books wondering how to explain the coherence and permanence of republicanism after independence into the twentieth century, and the rules and spaces that made possible a continued dialogue. ${ }^{86}$ References to the "hidden transcripts" behind these negotiations seem to doubt the sincerity of subaltern actors' utterances in front of that state. Instead of an open-ended dialogue that eventually shapes political regimes and identities, a stress on negotiation reduces political exchanges to something similar to the bartering between tourists and markets sellers: full of melodrama and false courtesy, but ultimately guided by results and determined by inequality of power. ${ }^{87}$ The problem is that this conclusion denies the historicity of language (it does not matter if it changes since it refers to the same, unchanging power) and its ability to change social relations — examined by Gramsci himself.

\footnotetext{
${ }^{86}$ Mallon, Peasant and Nation: The Making of Postcolonial Mexico and Peru, 24-25.

${ }^{87}$ See Peter Guardino's definition of hegemony as rules of the game that peasants must adopt if they want results, but something that has no influence on what they think. Peter Guardino, "'El carácter tumultuoso de esta gente": Los tumultos y la legitimidad en los pueblos oaxaqueños, 1768-1853," in Poder y legitimidad en México, Siglo XIX: Instituciones y cultura política, ed. Brian Connaughton (Mexico City: Universidad Autónoma Metropolitana-Miguel Angel Porrúa, 2003), 183. A more critical perspective in Peter F. Guardino, The Time of Liberty: Popular Political Culture in Oaxaca, 1750-1850, Latin America otherwise (Durham: Duke University Press, 2005)."Each and every inference about the attitude behind an act of deference must therefore be based on evidence external to the act itself." Scott, Domination and the Arts. We could juxtapose Habermas's emphasis on communicative action against Foucault's genealogy of power. Politically, Foucault's account lends itself for a radical redrawing of the relations of power, leaving rational discussion and the struggle for republican representation as a rather futile endeavors. Habermas' "immanent critique," on the other side, can be used to look critically at historical moments when modernity rejected dialogue and inclusiveness. Compare Michel Foucault, Microfisica del poder (Madrid: La Piqueta, 1980); Habermas, The Philosophical Discourse. For the Habermas-Foucault contraposition see Carlos Forment, "La sociedad civil en el Perú del siglo XIX: democrática o disciplinaria," in Ciudadanía política y formación de las naciones: Perspectivas históricas de América Latina, ed. Hilda Sábato (Mexico City: Fondo de Cultura Económica, 1999); Vinayak Chaturvedi, Mapping subaltern studies and the postcolonial (London: Verso, 2000), xi; Sarkar, "Orientalism Revisited," 241, for a critique of subalternists' use of Foucaldian power/knowledge.
} 
The central role of violence in the construction of Latin American polities is one field of research that promises to open new perspectives for the history of the public sphere in Latin America, and possibly beyond. Even if they doubt the sincerity of patriotism, Mallon and Vaughan see foreign interventions and revolutions as decisive moments in the integration of peasants into Mexico, either through nationalism or through the socially inclusive discourse of the post-revolutionary regime. Yet the military logic of these armed conflicts has not been included in cultural analyses of politics, in part because detailed studies of war in Latin America have traditionally been produced from a nationalist optic. The result is that violence tends to be interpreted as cathartic, irrational instants in national politics or in the best case as the framework for clientelistic mobilization. I would argue, however, that civil and military conflict is not out of the grasp of histories of the public sphere. In the history of Latin American public culture, concerns about honor, virtue and gossip did not preempt but, in fact, expected violence as a potential outcome of all exchanges. Utterances could be antagonistic, as in the judicial public opinion identified by Palti, and frequently lead to armed challenges against political regimes or individuals. Armed confrontations were not necessarily, as in Sabato's view, non-“rational and 'civilized' means of expressing opinion”: violence was formalized in ways that allowed its continuity as a dialogue. Dueling is one example of the civilizing of violence among upper classes, but there are other battlefields where the expressive function of violence was part of discursive public exchanges, from polemics about the personal merits of veterans to historical debates about past military episodes. Codes of honor were not limited to the regulation of duels: during the late nineteenth century they provided a common language for political elites to gain legitimacy as 
representatives of public opinion. Further examination of this language promises to bring about a better understanding of the exclusion of women from politics: not simply a "natural" condition of public life but an exclusion actively maintained by historical transformations of masculinity ${ }^{88}$ Formalistic military pronunciamientos (rebel calls to arms issued from barracks) in nineteenth-century Mexico usually did not require actual fighting. The dialogical premise was that, even if actual combat could be unbalanced, heroism made all parties equal—as General Pedro María Anaya told the U.S. commander who had just defeated him in Churubusco, in 1847: "If I had ammunition you would not be here. ${ }^{" 89}$ A gendered reexamination of caudillismo would undoubtedly throw new light on the constitution of new polities and probably help historicize natural notions about masculine power. Recent scholarly interest in masculinities in Latin America, for example, explores the use of male bodies and the public/private divide as key mechanism to secure gendered domination over public speech in the name of men's "sacrifice." ${ }^{90}$ Conversely, the enlightened "rational-critical debate" was a masculine

${ }^{88}$ See David S. Parker, "Law, Honor, and Impunity in Spanish America: The Debate over Dueling, 1870 1920," Law and History Review 19, no. 2 (2001); Sandra Gayol, "'Honor Moderno": The Significance of Honor in Fin-de-Siècle Argentina," Hispanic American Historical Review 84, no. 3 (2004); Connaughton, Illades, and Pérez Toledo, eds., Construcción de la legitimidad; Pablo Piccato, "Politics and the Technology of Honor: Dueling in Turn-of-the-Century Mexico," Journal of Social History 33, no. 2 (1999); William B. Taylor, Drinking, Homicide, and Rebellion in Colonial Mexican Villages (Stanford: Stanford University Press, 1989); Chasteen, "Violence for Show." For recent studies of honor see Lyman L. Johnson and Sonya Lipsett-Rivera, eds., The Faces of Honor, Sex, Shame, and Violence in Colonial Latin America (Alburquerque: University of New Mexico Press, 1998); Sueann Caulfield, Sarah C. Chambers, and Lara Putnam, eds., Honor, Status, and Law in Modern Latin America (Durham N.C.: Duke University Press, 2005).

${ }^{89}$ An heroic account of the war in Heriberto Frías, Episodios militares mexicanos: Principales Campañas, jornadas, batallas, combates y actos heroicos, que ilustran la historia del ejército nacional desde la Independencia hasta el triunfo definitivo de la República (Mexico City: Porrúa, 1987). The disciplining of soldiers in the late nineteenth century illustrates the connection between nationalism and the shaping of male bodies. See Peter M. Beattie, The tribute of Blood: Army, Honor, Race, and Nation in Brazil, 18641945, Latin America otherwise (Durham: Duke University Press, 2001). For studies on similar topics in the United States see Angus McLaren, The Trials of Masculinity: Policing Sexual Boundaries, 1870-1930 (Chicago: University of Chicago Press, 1997); Kristin L. Hoganson, Fighting for American Manhood: How Gender Politics Provoked the Spanish-American and Philippine-American Wars (New Haven Conn.: Yale University Press, 1998).

${ }^{90}$ Michael Warner, Publics and Counterpublics (New York, Cambridge, Mass.: Zone Books Distributed by MIT Press, 2002), 55, 57. See also Christian Thorne, "Thumbing Our Nose at the Public Sphere: Satire, the 
faculty, yet it did not eliminate the centrality of sentiment and gossip in bringing together a diversity of spectators and speakers. ${ }^{91}$ Chambers' focus on honor throws new light on the gendered nature of democratic life at the national level; the exclusion of women from the public sphere after independence, often lost to intellectual historians, corresponded with a redefinition of the manly virtues that shaped new democracies. ${ }^{92}$

Such reexamination could build a Latin American critique of the centrality of the individual in the emergence of the public sphere. Looking at the contested divide between public and private, histories of the public sphere informed by gender are also histories of the ways in which individuals defined themselves (a history of the self, in other words, without a psychoanalytic substratum). Ethnographic research like Laura Graham's study of communal assemblies shows how public discussions can avoid setting the focus on one voice; among the Xavante, decisions are the product of "a veritable collage of [simultaneous] voices" and "Individuals are dissociated from the content of their speech so that accountability does not reside with any particular speaker . . . but is distributed

Market, and the Invention of Literature," Publications of the Modern Language Association of America 116, no. 3 (2001); James Green, "Journalists and Dandies: Bohemian Male Sociability in Rio de Janeiro, 1870-1920" (paper presented at the Centenary of the Famous 41, Sexuality and Social Control in Latin America, 1901, Tulane University, New Orleans, November 2001); Matthew C. Gutmann, Changing men and masculinities in Latin America (Durham: Duke University Press, 2003); Irwin, Mexican Masculinities; Beattie, The tribute of Blood. There are many studies of the silencing of women in Latin American history. See, f. ex., Carmen Ramos and et al., Presencia y transparencia: La mujer en la historia de México (Mexico City: El Colegio de México, 1987). For Michael Warner this "principle of negativity" makes possible male domination over the bourgeois public sphere: men's ability to sacrifice their bodies and private interests makes them indispensable. Warner, Publics and Counterpublics, 165. Queer theory, with its questioning of the public-private refashioning of identities and bodies, about the discussions of "gender or sexual relations" in the public sphere. Warner, Publics and Counterpublics, 54.

${ }^{91}$ See, f. ex., Lomnitz-Adler, Deep Mexico, Silent Mexico, 157. See on sentiment Eugenia Lean, "'I Shot the Warlord": Female Self-Fashioning, Public Emotions and Mass Culture in 1930s China," (New York: 2004); Warner, Publics and Counterpublics, 51; Pierre Bourdieu, Masculine Domination (Cambridge, England: Polity Press, 2001). A feminist perspective is, as noted above, still central: Landes, "The Public and the Private." My own exploration of these theses in Piccato, "'El populacho" y la opinión pública"; Piccato, "Jurados de imprenta."

${ }^{92}$ Exclusion never quite took away from women a "central role ... in influencing popular opinion at the neighborhood level." Chambers, From Subjects to Citizens, 92. 
throughout the polity. ${ }^{.93}$ We can expect historians to draw inspiration from ethnographies in studying Latin American public actors' fluid movement between the representation of multiple and overlapping electoral constituencies, regions, cities, extended families and individual interests.

One last realm in which public-sphere centered analysis can productively engage studies of hegemony is the constitution of publics. Publics are audiences that define discourses and debates, both political forces and objects of discussion, susceptible to reason as much as emotions. A Foucaldian archeology of discourse could provide useful descriptive tools for discursive fields but does not help understanding the coming together of diverse actors to become interlocutors. Two fields where this tension is currently played out are those of the histories of medicine and of crime and punishment. From important studies focused on law, science and institutions, researchers are now turning to a more comprehensive study of the interaction of those disciplines with social actors and practices, and of the ways broader audiences received and reshaped ideas about disease and transgression. Political history could take some cues from this research. Just as popular audiences engaged the "estado médico-legal" to produce their own combination of biological explanations and old justice in Argentina, ${ }^{94}$ citizens in the new republics became interlocutors of the discourse of liberalism. Their coming together to reshape democracy and citizenship would be easier to comprehend from a dialogical

\footnotetext{
${ }^{93}$ Laura Graham, "A Public Sphere in Amazonia? The Depersonalized Collaborative Construction of Discourse in Xavante," American Ethnologist 20, no. 4 (1993): 736, 18. See also Goodman, "Public Sphere and Private Life: Toward a Synthesis of Current Historiographical Approaches to the Old Regime," 1, 5; Paul Friedrich, The Princes of Naranja: An Essay in Anthrohistorical Method (Austin: University of Texas Press, 1986). On communal consciousness, Chartterjee, "On Some Aspects," 13.

${ }^{94}$ Lila M. Caimari, Apenas un delincuente: Crimen, castigo y cultura en la Argentina, 1880-1955, 1. ed. (Buenos Aires: Siglo Veintiuno Editores Argentina, 2004). See also Katherine Elaine Bliss, Compromised Positions: Prostitution, Public Health, and Gender Politics in Revolutionary Mexico City (University Park: Pennsylvania State University Press, 2001); Ricardo Donato Salvatore, Carlos Aguirre, and Gilbert M. Joseph, Crime and Punishment in Latin America: Law and Society since Late Colonial Times (Durham $<$ N.C. $>$ : Duke University Press, 2001).
} 
perspective than from one that still assumes preexisting identities and clearly defined interests, and see class antagonism as a condition of public discourse. ${ }^{95}$ Forment shows how "counterpublics" emerged in nineteenth-century Peru as political discussion spread beyond the republic of letters, enabling "workers, artisans, indigenous peoples to enter the public sphere and broaden its agenda." 96 But "counterpublics" assumes one preexisting, opposed and normatively superior "public"-a "national" public which is not so often the object of central interest in studies of hegemony, as if the local were more tangible. But the public has a history in Latin America, too. As Sabato, Guerra and Annick Lempérière have noted, the category of el público was essential to nineteenthcentury political language and conceptualization of legitimacy. It implied, we might argue, the existence of a public sphere where different voices would be heard, even if they involved multiple, specific publics fighting for their agendas in ways that hardly resemble the universal literate public imagined by Kant. ${ }^{97}$ As studies of the public sphere after independence show, politization created publics that imagined nations. Debates about credit and tariff policies, for example, defined a public of citizens who expressed

\footnotetext{
${ }^{95}$ At the intersection of a Foucaldian study and a Gramscian study of hegemony, the emphasis on "articulation" over "representation" proposes that the creation of meanings precedes that of social actors. Mouffe and Laclau, Hegemonía y estrategia, 124, 29, 42-43. See Michel Foucault, La arqueología del saber (Mexico City: Siglo XXI, 1979); Habermas, "Further Reflections," 429. For the usefulness of Habermas to complete Foucault's agenda, see Landes, Women and the Public Sphere, 7. See also Carlos Aguirre and Ricardo Salvatore, "Introduction: Writing the History of Law, Crime, and Punishment in Latin America," in Crime and Punishment in Latin America: Law and Society since Late Colonial Times, ed. Ricardo Donato Salvatore, Carlos Aguirre, and Gilbert M. Joseph (Durham, N.C.: Duke University Press, 2001), 17; Michel Foucault, Discipline and Punish: The Birth of the Prison (New York: Vintage, 1979); Warner, Publics and Counterpublics; Lean, "'I Shot the Warlord"."

${ }^{96}$ Forment, "La sociedad civil," 204-07.

${ }^{97}$ Sabato, "On Political Citizenship"; Lempérière, "Reflexiones." For the Western European version see Melton, The Rise. See also Sennett, The Fall of Public Man. "By the public use of one's own reason I understand the use that anyone as a scholar makes of reason before the entire literate world." Emmanuel Kant, "What is Enlightenment?, 1784," http://www.fordham.edu/halsall/mod/kant-whatis.html.
} 
their common interests in a dialogue with national authorities, sometimes with

consequences for national unity. ${ }^{98}$

The interlocutors in those debates include workers talking to economists and national authorities, and also transnational actors. Studying publics and counterpublics, or hegemonic and counterhegemonic discourses, however, does not require the existence of multiple public spheres, or of one that is irrevocably fragmented by class or other differences. I would argue that those publics are better understood historically if placed in the framework of one national public sphere. Studies of Latin American artisans in the nineteenth century, for example, show a sustained desire to speak rationally, in the name of a respectable working class, to a national audience. This is clearer for the twentieth century: labor historians have looked at the combination of experience and language, rather than the homogenizing impact of industrialization, behind the consciousness that made possible mass mobilizations. ${ }^{99}$ Working-class publics came together through discourses and debates that provided the conceptual means to think about common interests and to address the state. Were Argentine workers "los trabajadores" before Peronism? Recent studies examine Peronist efforts to create a political base through media and a language that incorporated groups traditionally excluded from the Argentine

${ }^{98}$ Forment, Democracy in Latin America, 126; Paul Gootenberg, "North-South: Trade Policy, Regionalism and Caudillismo in Post-Independence Peru," Journal of Latin American Studies 23, no. 2 (1991).

${ }^{99}$ On artisans in the public sphere see Carlos Illades, Hacia la república del trabajo. La organización artesanal en la ciudad de México, 1853-1876 (Mexico City: El Colegio de México-Universidad Autónoma Metropolitana, 1996); Gootenberg, Imagining Development. On multiple public spheres, see Negt and Kluge, Public Sphere and Experience; Emilia Viotti da Costa, "Experience versus Structures: New Tendencies in the History of Labor and the Working Class in Latin America--What Do We Gain? What Do We Lose?," International Labor and Working-Class History 36 (1989). On consciousness and structural factors in the emergence of Peronism see the classic debate in Tulio Halperin Donghi, "Algunas observaciones sobre Germani," Desarrollo Económico 14, no. 56 (1975); Gino Germani, "El surgimiento del peronismo: el rol de los obreros y de los migrantes internos," 14, no. 56 (1975). For labor historians' focus on experience to make sense of responses to changing political circumstances see Daniel James, Resistance and integration. Peronism and the Argentine working class, 1946-1976 (New York: Cambridge University Press, 1990); Joel Wolfe, Working Women, Working Men: Sao Paulo and the Rise of Brazil's Industrial Working Class, 1900-1955 (Durham: Duke University Press, 1993); Peter Winn, Weavers of revolution. The Yarur workers and Chile's road to socialism (New York: Oxford University Press, 1986). 
public sphere on account of race, class and gender. The process made the intersections of class, gender, personal loyalty and nationalism legitimate objects of debate by a broad range of interlocutors. ${ }^{100}$ In Doña María's Story, for example, Daniel James uses interviews to examine Peronist workers' own reconstruction of their personal and collective historical role in "a newly enlarged public sphere."101

\section{Conclusion: Using the map against fragmentation}

If we stress violence and class, ethnic or gender divides, the national public spheres explored by Guerra seem to shrink beyond recognition. Historians of Latin American hegemonies use the category of fragmentation to explain the problem of the absence of coherent territories and polities, and weak bourgeois values in modern Latin America. Yet their valuable findings are not enough to dismiss the productive survey of the public sphere that others, also mentioned in these pages, have undertaken. In these accounts, multiple actors addressed the state and civil society, assuming (as a key part of their notion of citizenship) that they could be involved in dialogues in the public sphere, and that this public sphere was one, where all rational opinions counted. Access, reason, public/private, individuality, representation, vecindad: all these elements of the picture

\footnotetext{
${ }^{100}$ Mariano Ben Plotkin, Mañana es San Perón: A cultural history of Peron's Argentina, Latin American silhouettes (Wilmington, Del.: SR Books, 2003), 198. On populism as style, see Alan Knight, "Populism and Neo-populism in Latin America, Especially Mexico," Journal of Latin American Studies 30, no. 2 (1998); Ernesto Laclau, "Populismo y transformación del imaginario político en América Latina," Boletín de Estudios Latinoamericanos y del Caribe, no. 42 (1987).

${ }^{101}$ Daniel James, Doña María's Story: Life History, Memory, and Political Identity, Latin America otherwise (Durham N.C.: Duke University Press, 2000), 219-20. On workers' use of public spaces Daniel James, "October 17th and 18th, 1945: Mass Protest, Peronism and the Argentine Working Class," Journal of Social History 21, no. 2 (1988); Georg Leidenberger, "Habermas en el Zócalo: la "transformación de la esfera pública" y la política del transporte público en la ciudad de México, 1900-1947," in Actores, espacios y debates en la historia de la esfera pública en la ciudad de México, ed. Cristina Sacristán and Pablo Piccato (Mexico City: Instituto Mora, 2005).
} 
have their own history. The literature examined here leaves no doubt that their intersection in Latin America after independence was original and productive.

What made a meeting of wills possible was the shared goal of intervening in conversations that brought all members of the polity together. Independence meant the sudden politicization of publicity. Achieving an inclusive, non-coercive dialogue among old and new actors is still the object of ongoing struggles in Latin America. From the methodological point of view, the public sphere model offers a consistent framework to study the desire to have those conversations in a language that could be understood by all, in societies where languages as often separate as they unite. Since the theory casts a wide net over diverse phenomena, historians are justifiably wary of creating a new grand narrative that would rejuvenate enlightened homogenization and teleology. But the cost of doing nothing in the current historiographical landscape (that is, of accepting current disciplinary and theoretical divides) might be greater than the risk of testing new interpretive models against prevalent frameworks.

A critical Latin American perspective on the public sphere should incorporate gender, class and cultural difference, and account for a strong colonial and urban background. The result will challenge but continue to engage narratives of republicanism and liberalism. A dialogue between a Habermasian perspective and others based on Gramscian or Foucaldian theoretical models is not an impossibility, and will provide a common vocabulary for diverse subfields and traditions within Latin American historiography. In the territory surveyed here, historians' idioms or national audiences may be less relevant, in the end, than their choices about research objects: broadening the definition of politics with a notion of culture as a purely symbolic realm may in the end 
only add new thematic chapters to the elite-centered national histories dominating Latin American classrooms; too keen a search for fragmented discourses and counterpublics may break down history into plots that, although innovative, pose no threat to "important" themes. As a set of historical coordinates, a history of the public sphere in Latin America will advance the alliance of "small" research, on local politics and languages, privacy and bodies, with the "large" scale of inquiry about nationalism and representation. In order to do so, however, the category of public sphere will have to retain its unitary character, as the common, non-coercive realm for "people's public use of their reason" that is central to its original formulation. Otherwise, the dialogue that interests researchers and gives political relevance to the model would become irrelevant, making the model itself the map of an island without a place. 


\section{Bibliography:}

Hispanic American Historical Review 79, no. 2 (1999).

Aguila Peralta, Alicia del. Callejones y mansiones: Espacios de opinión pública y redes sociales y políticias en la Lima del 900. Lima: Pontificia Universidad Católica del Perú, 1997.

Aguilar, José Antonio. "Dos conceptos de república." In El republicanismo en hispanoamérica: Ensayos de historia intelectual y politica, edited by José Antonio Aguilar and Rafael Rojas, 57-85. Mexico City: Centro de Investigación y Docencia ; Fondo de Cultura Económica, 2002.

Aguilar, José Antonio, and Rafael Rojas, eds. El republicanismo en hispanoamérica: Ensayos de historia intelectual y política. 1a ed, Sección de obras de historia. Mexico City: Centro de Investigación y Docencia ; Fondo de Cultura Económica, 2002.

Aguirre, Carlos, and Ricardo Salvatore. "Introduction: Writing the History of Law, Crime, and Punishment in Latin America." In Crime and Punishment in Latin America: Law and Society since Late Colonial Times, edited by Ricardo Donato Salvatore, Carlos Aguirre and Gilbert M. Joseph, 1-35. Durham, N.C.: Duke University Press, 2001.

Alonso, Paula, ed. Construcciones impresas: Panfletos, diarios y revistas en la formación de los estados nacionales en América Latina, 1820-1920. Buenos Aires: FCE, 2004.

Anderson, Benedict. Imagined Communities: Reflections on the Origin and Spread of Nationalism. New York-Londres: Verso, 1983.

Annino, Antonio. "Cádiz y la revolución territorial de los pueblos mexicanos 18121821." In Historia de las elecciones en Iberoamérica, siglo XIX: De la formación del espacio político nacional, edited by Antonio Annino, 177-226. Buenos Aires: FCE, 1995.

. "Ciudadanía versus gobernabilidad republicana en México: Los orígenes de un dilema." In Ciudadanía política y formación de las naciones: Perspectivas históricas de América Latina, edited by Hilda Sábato, 62-93. Mexico City: Fce, 1999.

- "El Jano bifronte: Los pueblos y los orígenes del liberalismo en México." In Crisis, Reforma y Revolución: México: Historias de Fin de Siglo, edited by Leticia Reina and Elisa Servín, 209-51. México, D.F.: Taurus : CONACULTAINAH, 2002.

— - ed. Historia de las elecciones en Iberoamérica, siglo XIX: De la formación del espacio político nacional. Buenos Aires: FCE, 1995.

Annino, Antonio, and François-Xavier Guerra. Inventando la nación: Iberoamérica siglo $X I X$. 1. ed. Mexico City: Fondo de Cultura Económica, 2003.

Arnold, David. "Gramsci and Peasant Subalternity in India." In Mapping subaltern studies and the postcolonial, edited by Vinayak Chaturvedi, 24-49. London: Verso, 2000.

Arrom, Silvia. "Una nueva sociabilidad femenina: Las señoras de la caridad de San Vicente de Paul, 1863-1910." Paper presented at the V Seminario Internacional Sobre la Experiencia Institucional de la Ciudad de México: las Sociabilidades en 
la ciudad de México del siglo XIX a la Revolución,, Mexico City, 23 de junio de 20052005.

Baker, Keith Michael. "Defining the Public Sphere in Eighteenth-Century France:

Variations on a Theme by Habermas." In Habermas and the Public Sphere, edited by Craig Calhoun, 182-211. Cambridge, Mass.: MIT, 1997.

- Inventing the French Revolution: Essays on French Political Culture in the Eighteenth Century. Cambridge: Cambridge University Press, 1990.

Bantjes, Adrian A. As if Jesus Walked on Earth: Cardenismo, Sonora, and the Mexican Revolution. Wilmington, Del.: SR Books, 1998.

Beattie, Peter M. The tribute of Blood: Army, Honor, Race, and Nation in Brazil, 18641945, Latin America otherwise. Durham: Duke University Press, 2001.

Beezley, William H. Cheryl English Martin, and eds William E. French. Rituals of Rule, Rituals of Resistance. Wilmington: Scholarly Resources, 1994.

Bell, David A. "The "Public Sphere," the State, and the World of Law in EighteenthCentury France." French Historical Studies 17, no. 4 (1992): 912-34.

Benhabib, Seyla. "Models of Public Space: Hannah Arendt, the Liberal Tradition, and Jürgen Habermas." In Habermas and the Public Sphere, edited by Craig Calhoun, 73-98. Cambridge, Mass.: MIT, 1997.

Blackbourn, David. "The German Bourgeoisie: An Introduction." In The German Bourgeoisie. Essays on the social history of the German middle class from the late eighteenth to the early twentieth century, edited by David Blackbourn and ed Richard J. Evans, 1-45. London and New York, 1992.

Bliss, Katherine Elaine. Compromised Positions: Prostitution, Public Health, and Gender Politics in Revolutionary Mexico City. University Park: Pennsylvania State University Press, 2001.

Borges, Jorge Luis. Obras completas II 1952-1972. Barcelona: Emecé Editores, 1996. Bourdieu, Pierre. Masculine Domination. Cambridge, England: Polity Press, 2001.

Boyer, Christopher R. Becoming Campesinos: Politics, Identity, and Agrarian Struggle in Postrevolutionary Michoacan, 1920-1935. Stanford, Calif.: Stanford University Press, 2003.

Brinkley, Alan. "What's Next? The mourning period is over. Now, four simple guidelines for becoming a majority party." The American Prospect Online Edition, January 2004.

Caimari, Lila M. Apenas un delincuente: Crimen, castigo y cultura en la Argentina, 1880-1955. 1. ed. Buenos Aires: Siglo Veintiuno Editores Argentina, 2004.

Calhoun, Craig. "Introduction: Habermas and the Public Sphere." In Habermas and the Public Sphere, edited by Craig Calhoun, 1-48. Cambridge, Mass.: MIT, 1997.

Calhoun, Craig J. Habermas and the Public Sphere, Studies in contemporary German social thought. Cambridge, Mass.: MIT Press, 1992.

Castro, Miguel Angel, and Universidad Nacional Autónoma de México. Seminario de Bibliografía Mexicana del Siglo XIX., eds. Tipos y caracteres : la prensa mexicana (1822-1855) ; memoria del coloquio celebrado los días 23, 24 y 25 septiembre de 1998. 1. ed. México: Instituto de Investigaciones Bibliográficas Seminario de Bibliografía Mexicana del Siglo XIX Universidad Nacional Autónoma de México, 2001. 
Caulfield, Sueann, Sarah C. Chambers, and Lara Putnam, eds. Honor, Status, and Law in Modern Latin America. Durham N.C.: Duke University Press, 2005.

Celis de la Cruz, Martha. "El empresario Vicente García Torres (1811-1894)." In Tipos y caracteres : la prensa mexicana (1822-1855) ; memoria del coloquio celebrado los días 23, 24 y 25 septiembre de 1998, edited by Miguel Angel Castro, 147-59. México: Instituto de Investigaciones Bibliográficas Seminario de Bibliografía Mexicana del Siglo XIX Universidad Nacional Autónoma de México, 2001.

Chakrabarty, Dipesh. "Radical Histories and Question of Enlightenment Rationalism: Some Recent Critiques of Subaltern Studies." In Mapping subaltern studies and the postcolonial, edited by Vinayak Chaturvedi, 256-80. London: Verso, 2000.

Chambers, Sarah C. From Subjects to Citizens: Honor, Gender and Politics in Arequipa, Peru, 1780-1854. University Park, PA: Pennsylvania State University, 1999.

Chartier, Roger. The Cultural Origins of the French Revolution. tr. Lydia G. Cochrane. Durham: Duke University Press, 1991.

Chartterjee, Partha. "The Nation and Its Peasants." In Mapping subaltern studies and the postcolonial, edited by Vinayak Chaturvedi, 8-23. London: Verso, 2000.

Chasteen, John Charles. "Violence for Show: Knife Duelling on a Nineteenth-Century Cattle Frontier." In The Problem of Order in Changing Societies: Essays on Crime and Policing in Argentina and Uruguay, 1750-1940, edited by Lyman L. Johnson. Albuquerque: University of New Mexico Press, 1990.

Chaturvedi, Vinayak. Mapping subaltern studies and the postcolonial. London: Verso, 2000.

Cohen, Jean L., and Andrew Arato. Civil society and political theory, Studies in contemporary German social thought. Cambridge, Mass.: MIT Press, 1992.

Connaughton, Brian, Carlos Illades, and Sonia Pérez Toledo, eds. La construcción de la legitimidad política en México. Mexico City: El Colegio de MichoacánUniversidad Autónoma Metropolitana-Universidad Nacional Autónoma de México-El Colegio de México, 1999.

Cruz Seoane, María. Oratoria y periodismo en España del siglo XIX. Valencia: Fundación Juan March, 1977.

Davis, Diane E. "El rumbo de la esfera pública: Influencias locales, nacionales e internacionales en la urbanización del centro de la ciudad de México, 1910-1950." In Actores, espacios y debates en la historia de la esfera pública en la ciudad de México, edited by Cristina Sacristán and Pablo Piccato, 233-71. Mexico City: Instituto Mora, 2005.

De la Fuente, Ariel. Children of Facundo: Caudillo and Gaucho Insurgency During the Argentine State-Formation Process (La Rioja, 1853-1870). Durham N.C.: Duke University Press, 2000.

Deas, Malcom. Del poder y la gramática: y otros ensayos sobre historia, politica y literatura colombianas. Bogotá: Tercer Mundo Editores, 1993.

Eley, Geoff. "The British Model and the German Road: Rethinking the Course of German History Before 1914." In The Peculiarities of German History: Bourgeois Society and Politics in Nineteenth-Century Germany, edited by David Blackbourn and Geoff Eley, 39-155. Oxford: Oxford University Press, 1984. . "Nations, Publics, and Political Cultures: Placing Habermas in the Nineteenth Century." In Culture/Power/History: A Reader in Contemporary Social Theory, 
edited by Nicholas B. Dirks, Geoff Eley and Sherry B. Ortner. Princeton:

Princeton University Press, 1994.

Escalante, Fernando. Ciudadanos imaginarios: Memorial de los afanes y desventuras de la virtud y apología del vicio triunfante en la República Mexicana: Tratado de Moral Pública. Mexico: Colegio de México, 1993.

Farge, Arlette. Subversive Words: Public Opinion in Eighteenth-Century France. Translated by Rosemary Morris. University Park: The Pennsylvania State University Press, 1994.

Forment, Carlos. "La sociedad civil en el Perú del siglo XIX: democrática o disciplinaria." In Ciudadanía política y formación de las naciones: Perspectivas históricas de América Latina, edited by Hilda Sábato. Mexico City: Fondo de Cultura Económica, 1999.

Forment, Carlos A. Democracy in Latin America, 1760-1900, Morality and society. Chicago: University of Chicago Press, 2003.

Foucault, Michel. Discipline and Punish: The Birth of the Prison. New York: Vintage, 1979.

—. La arqueología del saber. Mexico City: Siglo XXI, 1979.

-. Microfísica del poder. Madrid: La Piqueta, 1980.

Fraser, Nancy. "Rethinking the Public Sphere: A Contribution to the Critique of Actually Existing Democracy." Social Text, no. 25/26 (1990): 56-80.

Frías, Heriberto. Episodios militares mexicanos: Principales Campañas, jornadas, batallas, combates y actos heroicos, que ilustran la historia del ejército nacional desde la Independencia hasta el triunfo definitivo de la República. Mexico City: Porrúa, 1987.

Friedrich, Paul. The Princes of Naranja: An Essay in Anthrohistorical Method. Austin: University of Texas Press, 1986.

Furet, François. Penser la Révolution française. Paris: Gallimard, 1978.

Gayol, Sandra. ""Honor Moderno": The Significance of Honor in Fin-de-Siècle Argentina." Hispanic American Historical Review 84, no. 3 (2004): 475-98.

Germani, Gino. "El surgimiento del peronismo: el rol de los obreros y de los migrantes internos." 14, no. 56 (1975): 435-88.

González Bernaldo, Pilar. "Sociabilidad, espacio urbano y politización en la ciudad de Buenos Aires (1820-1852)." In La vida política en la Argentina del siglo XIX: armas, votos y voces, edited by Hilda Sabato and Alberto Rodolfo Lettieri, 191204. Buenos Aires: Fondo de Cultura Económica, 2003.

Goodman, Dena. "Public Sphere and Private Life: Toward a Synthesis of Current Historiographical Approaches to the Old Regime." History and Theory 31, no. 1 (1992): 1-20.

Gootenberg, Paul. Imagining Development: Economic Ideas in Peru's "Fictitious Prosperity" of Guano, 1840-1880. Berkeley, Calif.: University of California Press, 1993.

—. "North-South: Trade Policy, Regionalism and Caudillismo in Post-Independence Peru." Journal of Latin American Studies 23, no. 2 (1991): 273-308.

Gordon, Daniel. "Philosophy, Sociology, and Gender in the Enlightenment Conception of Public Opinion." French Historical Studies 17, no. 4 (1992): 882-911. 
Graham, Laura. "A Public Sphere in Amazonia? The Depersonalized Collaborative Construction of Discourse in Xavante." American Ethnologist 20, no. 4 (1993): 717-41.

Graham, Richard. Patronage and politics in Nineteenth Century Brazil. Stanford: Stanford University Press, 1990.

Granados, Luis Fernando. "Calpultin decimonónicos: Aspectos nahuas de la cultura política de la ciudad de México." In Actores, espacios y debates en la historia de la esfera pública en la ciudad de México, edited by Pablo Piccato and Cristina Sacristán, 41-66. Mexico City: Instituto Mora, 2005.

Green, James. "Journalists and Dandies: Bohemian Male Sociability in Rio de Janeiro, 1870-1920." Paper presented at the Centenary of the Famous 41, Sexuality and Social Control in Latin America, 1901, Tulane University, New Orleans, November 2001.

Guardino, Peter. "Barbarism or republican law?: Guerrero's peasants and national politics, 1820-1846." Hispanic American Historical Review 75, no. 2 (1995): 185213.

. "'El carácter tumultuoso de esta gente": Los tumultos y la legitimidad en los pueblos oaxaqueños, 1768-1853." In Poder y legitimidad en México, Siglo XIX: Instituciones y cultura política, edited by Brian Connaughton, 181-205. Mexico City: Universidad Autónoma Metropolitana-Miguel Angel Porrúa, 2003.

Guardino, Peter F. Peasants, Politics, and the Formation of Mexico's National State: Guerrero, 1800-1857. Stanford, Calif.: Stanford University Press, 1996.

- The Time of Liberty: Popular Political Culture in Oaxaca, 1750-1850, Latin America otherwise. Durham: Duke University Press, 2005.

Guerra, Francois-Xavier. México: del Antiguo Régimen a la Revolución. Mexico City: Fondo de Cultura Económica, 1988.

Guerra, François-Xavier. Modernidad e independencias: Ensayos sobre las revoluciones hispánicas. 3a ed, Colecciones MAPFRE 1492. Madrid, Mexico City: Editorial MAPFRE; Fondo de Cultura Económica, 2000.

Guerra, Francois-Xavier, and Annick Lempérière. "Introducción." In Los espacios públicos en Iberoamérica: Ambigüedades y problemas: Siglos XVIII-XIX, edited by Francois-Xavier Guerra and Annick Lempérière, 5-21. México: Fondo de Cultura Económica, 1999.

Guerra, Francois-Xavier, and Annick Lempérière. Los espacios públicos en Iberoamérica: Ambigüedades y problemas: Siglos XVIII-XIX. México: Fondo de Cultura Económica, 1999.

Guha, Ranajit. "On Some Aspects of the Historiography of Colonial India." In Mapping subaltern studies and the postcolonial, edited by Vinayak Chaturvedi, 1-7. London: Verso, 2000.

—. A Subaltern studies reader, 1986-1995. Minneapolis ; London: University of Minnesota Press, 1997.

Gutmann, Matthew C. Changing men and masculinities in Latin America. Durham: Duke University Press, 2003.

Guzman Pérez, Moises. "Practiques de sociabilité et de lecture en Nouvelle-Espagne: L'evêche de Michoacán (1870-1810)." Bulletin de L'Institut Pierre Renouvin, no. 17 (2003): 51-63. 
Haber, Stephen. "Anything Goes: Mexico's 'New" Cultural History." Hispanic American Historical Review 79, no. 2 (1999): 309-30.

Habermas, Jurgen. "Discourse Ethics: Notes on a Program of Philosophical Justification." In Moral consciousness and communicative action, 42-115. Cambridge, Mass.: MIT Press, 1990.

. "Philosophy as Stand-In and Interpreter." In Moral consciousness and communicative action, 1-20. Cambridge, Mass.: MIT Press, 1990.

. "The Public Sphere: An Encyclopedia Article." New German Critique, no. 3 (1974): 49-55.

. The Theory of Communicative Action Vol. 1 Reason and the Rationalization of Society. Translated by Thomas McCarthy. Boston: Beacon Press, 1984.

Habermas, Jürgen. Ciencia y técnica como "ideología". Mexico City: Rei, 1993.

_. "Further Reflections on the Public Sphere." In Habermas and the Public Sphere, edited by Craig Calhoun, 421-61. Cambridge, Mass.: MIT, 1997.

- The Philosophical Discourse of Modernity: Twelve Lectures, Studies in contemporary German social thought. Cambridge, Mass.: MIT Press, 1987.

- The Structural Transformation of the Public Sphere: An Inquiry into a Category of Bourgeois Society. Cambridge, Mass.: MIT, 1991.

Hale, Charles. "Edmundo O'Gorman y la historia nacional." Signos Históricos 2, no. 3 (2000): 11-28.

Halperin Donghi, Tulio. "Algunas observaciones sobre Germani." Desarrollo Económico 14, no. 56 (1975): 765-81.

Halperín Donghi, Tulio. The Contemporary History of Latin America. Translated by John Charles Chasteen, Latin America in translation/en traducción/em tradução.

Durham, N.C.: Duke University Press, 1993.

- Revolución y guerra. Formación de una élite dirigente en la Argentina criolla. México: Siglo Veintiuno, 1979.

Hernández Chávez, Alicia. La tradición republicana del buen gobierno. 1. ed, Sección de obras de historia. México, D.F.: El Colegio de México : Fideicomiso Historia de las Américas : Fondo de Cultura Económica, 1993.

Herrejón Peredo, Carlos. "Sermones y discursos del primer imperio." In Construcción de la legitimidad política en México, edited by Carlos Illades, Brian Connaughton and Sonia Pérez Toledo, 153-67. Zamora: Colegio de Michoacán, 1999.

Herzog, Tamar. Defining Nations: Immigrants and Citizens in Early Modern Spain and Spanish America. New Haven: Yale University Press, 2003.

Hoganson, Kristin L. Fighting for American Manhood: How Gender Politics Provoked the Spanish-American and Philippine-American Wars. New Haven Conn.: Yale University Press, 1998.

Hohendahl, Peter Uwe. "The Public Sphere: Models and Boundaries." In Habermas and the Public Sphere, edited by Craig Calhoun, 99-108. Cambridge, Mass.: MIT, 1997.

Hurd, Madeleine. Public Spheres, Public Mores, and Democracy: Hamburg and Stockholm, 1870-1914, Social history, popular culture, and politics in Germany. Ann Arbor: University of Michigan Press, 2000. 
Illades, Carlos. Hacia la república del trabajo. La organización artesanal en la ciudad de México, 1853-1876. Mexico City: El Colegio de México-Universidad Autónoma Metropolitana, 1996.

Illades, Carlos, and Kuri Ariel Rodríguez, eds. Instituciones y ciudad. Ocho estudios históricos sobre la ciudad de México. Mexico City: FP-SONES-Uníos, 2000.

Irwin, Robert McKee. Mexican Masculinities. Minneapolis: University of Minnesota Press, 2003.

Ives, Peter. Gramsci's Politics of Language: Engaging the Bakhtin Circle and the Frankfurt School. Toronto: University of Toronto Press, 2004.

Jaffary, Nora E. False Mystics: Deviant Orthodoxy in Colonial Mexico, Engendering Latin America. Lincoln: University of Nebraska Press, 2004.

Jaksic, Ivan. The Political Power of the Word: Press and Oratory in Nineteenth-Century Latin America. London: Institute of Latin American Studies, 2002.

James, Daniel. Doña María's Story: Life History, Memory, and Political Identity, Latin America otherwise. Durham N.C.: Duke University Press, 2000. . "October 17th and 18th, 1945: Mass Protest, Peronism and the Argentine Working Class." Journal of Social History 21, no. 2 (1988): 441-61.

- Resistance and integration. Peronism and the Argentine working class, 19461976. New York: Cambridge University Press, 1990.

Johnson, Lyman L., and Sonya Lipsett-Rivera, eds. The Faces of Honor, Sex, Shame, and Violence in Colonial Latin America. Alburquerque: University of New Mexico Press, 1998.

Joseph, Gilbert M., and Daniel Nugent, eds. Everyday Forms of State Formation: Revolution and the Negotiation of Rule in Modern Mexico. Durham: Duke University Press, 1994.

Kant, Emmanuel. "What is Enlightenment?, 1784." http://www.fordham.edu/halsall/mod/kant-whatis.html.

Knight, Alan. "Populism and Neo-populism in Latin America, Especially Mexico." Journal of Latin American Studies 30, no. 2 (1998): 223-48.

_ . "Subalterns, Signifiers, and Statistics: Perspectives on Mexican Historiography." Latin American Research Review 37, no. 2 (2002): 136-58.

_. "Subalterns, Signifiers, And Statistics: Perspectives on Mexican Historiography." Latin American Research Review 37, no. 2 (2002): 136-58.

Laclau, Ernesto. "Populismo y transformación del imaginario político en América Latina." Boletín de Estudios Latinoamericanos y del Caribe, no. 42 (1987): 25-38.

Landes, Joan B. "The Public and the Private Sphere: A Feminist Reconsideration." In Feminism, the Public and the Private, edited by Joan B. Landes, 135-63. Oxford: Oxford University Press, 1998.

- Women and the Public Sphere in the Age of the French Revolution. Ithaca: Cornell University Press, 1988.

Lean, Eugenia. "'I Shot the Warlord": Female Self-Fashioning, Public Emotions and Mass Culture in 1930s China." New York, 2004.

Leidenberger, Georg. "Habermas en el Zócalo: la "transformación de la esfera pública" y la política del transporte público en la ciudad de México, 1900-1947." In Actores, espacios y debates en la historia de la esfera pública en la ciudad de México, 
edited by Cristina Sacristán and Pablo Piccato, 179-97. Mexico City: Instituto Mora, 2005.

Lempérière, Annick. Entre dieu et le roi, la république: Mexico, XVIe-XIXe siècle, Histoire ; 65. Paris: Belles lettres, 2004.

- "Reflexiones sobre la terminología política del liberalismo." In Construcción de la legitimidad politica en México, edited by Carlos Illades, Brian Connaughton and Sonia Pérez Toledo, 35-56. Zamora: Colegio de Michoacán, 1999.

Lira, Andrés. Comunidades indígenas frente a la ciudad de México: Tenochtitlan y Tlatelolco, sus pueblos y barrios, 1812-1919. Mexico City: El Colegio de México, 1995.

Lomnitz-Adler, Claudio. Deep Mexico, Silent Mexico: An Anthropology of Nationalism, Public worlds ; v. 9. Minneapolis: University of Minnesota Press, 2001.

_. Las salidas del laberinto: Cultura e ideologia en el espacio nacional mexicano. 1. ed. ed. Mexico City: J. Moritz : Planeta, 1995.

Lomnitz, Claudio. "Barbarians at the Gate? A Few Remarks on the Politics of the 'New Cultural History of Mexico'." Hispanic American Historical Review 79, no. 2 (1999): 367-83.

- Exits from the Labyrinth: Culture and Ideology in the Mexican National Space. Berkeley: University of California Press, 1992.

MacCalman, Iain. Radical Underworld: Prophets, Revolutionaries and Pornographers in London, 1795-1840. London: Clarendon, 1992.

Mah, Harold. "Phantasies of the Public Sphere: Rethinking the Habermas of Historians." Journal of Modern History 72, no. 1 (2000): 153-82.

Mallon, Florencia. Peasant and Nation: The Making of Postcolonial Mexico and Peru. Princeton: Princeton University Press, 1995.

. "The Promise and Dilemma of Subaltern Studies: Perspectives from Latin American History." American Historical Review 99, no. 5 (1994): 1491-515.

Maza, Sarah C. Private Lives and Public Affairs: The Causes Célèbres of Prerrevolutionary France. Berkeley: University of California Press, 1993.

McCarthy, Thomas A. The critical theory of Jürgen Habermas. 1st MIT Press paperback ed. Cambridge, Mass.: MIT Press, 1981.

McEvoy, Carmen. La utopía republicana: Ideales y realidades en la formación de la cultura política peruana, 1871-1919. 1a ed. Lima, Perú: Pontificia Universidad Católica del Perú, 1997.

—. "'Seríamos excelentes vasallos y nunca ciudadanos': prensa republicana y cambio social en Lima, 1791-1822." In The Political Power of the Word: Press and Oratory in Nineteenth-Century Latin America, edited by Ivan Jaksic, 34-63. London: Institute of Latin American Studies, 2002.

McLaren, Angus. The Trials of Masculinity: Policing Sexual Boundaries, 1870-1930. Chicago: University of Chicago Press, 1997.

Melton, James Van Horn. The Rise of the Public in Enlightenment Europe, New approaches to European history. New York: Cambridge University Press, 2001.

Montaldo, Graciela. Ficciones culturales y fábulas de identidad en América Latina. Rosario, Argentina: Beatriz Viterbo Editora, 1999. 
Mouffe, Chantal, and Ernesto Laclau. Hegemonía y estrategia socialista: Hacia una radicalización de la democracia. Translated by Ernesto Laclau. Buenos Aires: Fondo de Cultura Económcia, 2004.

Myers, Jorge. "Las paradojas de la opinión: El discurso político rivadaviano y sus dos polos: El "gobierno de las luces" y "la opinión pública, reina del mundo"." In La vida politica en la Argentina del siglo XIX : armas, votos y voces, edited by Hilda Sabato and Alberto Rodolfo Lettieri, 75-95. México ; Estados Unidos de América ; Buenos Aires: Fondo de Cultura Económica, 2003.

Negt, Oskar, and Alexander Kluge. Public Sphere and Experience: Toward an Analysis of the Bourgeois and Proletarian Public Sphere, Theory and history of literature ; v. 85. Minneapolis: University of Minnesota Press, 1993.

New Cultural, History. Hispanic American Historical Review 79:2 (May 1999), edited by Susan Deans-Smith and Gilbert M. Joseph.

O'Gorman, Edmundo. "Hegel y el moderno panamericanismo." Letras de México 2, no. 8 (1939): 14-15.

Ochoa Campos, Moises. Reseña histórica del periodismo mexicano. Mexico: Porrua, 1968.

"Oxford English Dictionary." Oxford University Press, http://www.oed.com/.

Oxhorn, Phillip. "When Democracy isn't all that Democratic: Social Exclusion and the Limits of the Public Sphere in Latin America." In The North-South Agenda, 23. Miami: North-South Center, University of Miami, 2001.

Ozouf, Mona. "Le concept d'opinion publique au XVIIIème siècle." In L'Homme régénéré. Essais sur la Révolution française. Paris: Gallimard, 1989.

Palti, Elías José. "Introducción." In La política del disenso: La "polémica en torno al monarquismo" (México, 1848-1850)... y las aporías del liberalismo, edited by Elías José Palti, 7-58. Mexico City: Fondo de Cultura Económica, 1998.

_ L La invención de una legitimidad: Razón y retórica en el pensamiento mexicano del siglo XIX (Un estudio sobre las formas del discurso político). Mexico City: Fondo de Cultura Económica, 2005.

— - ed. La política del disenso: La "polémica en torno al monarquismo" (México, 1848-1850)... y las aporías del liberalismo. Mexico City: Fondo de Cultura Económica, 1998.

— . "La Sociedad Filarmónica del Pito. Ópera, prensa y política en la República Restaurada (México, 1867-1976)." Historia Mexicana 52, no. 4 (2003). . "La Sociedad Filarmónica del Pito: Ópera, prensa y política en la República Restaurada (México, 1867-1876)." Paper presented at the Construcciones impresas. Diarios, periódicos y revistas en la formación de los estados nacionales en América Latina y Estados Unidos (1820-1920), Buenos Aires, May 2002. . "La transformación del liberalismo mexicano en el siglo XIX: Del modelo jurídico de la opinión pública al modelo estratégico de la sociedad civil." In Actores, espacios y debates en la historia de la esfera pública en la ciudad de México, edited by Pablo Piccato and Cristina Sacristán, 67-95. Mexico City: Instituto Mora, 2005.

. "Las polémicas en el liberalismo argentino: Sobre virtud, republicanismo y lenguaje." In El republicanismo en hispanoamérica: Ensayos de historia intelectual y política, edited by José Antonio Aguilar and Rafael Rojas, 167-209. 
Mexico City: Centro de Investigación y Docencia ; Fondo de Cultura Económica, 2002.

. "Los diarios y el sistema político mexicano en tiempos de la República Restaurada (1867-1876)." In Construcciones impresas. Panfletos, diarios y revistas en la formación de los estados nacionales en América Latina, 1820-1920, edited by Paula Alonso, 167-81. Buenos Aires: FCE, 2004.

Palti, José Elías. "Recent studies on the emergence of a Public sphere in Latin America." Latin American Research Review 36, no. 2 (2001).

Pani, Erika. Para mexicanizar el Segundo Imperio: el imaginario politico de los imperialistas. 1. ed. México, D.F.: Colegio de México Centro de Estudios Históricos : Instituto de Investigaciones Dr. José María Luis Mora, 2001.

Parker, David S. "Law, Honor, and Impunity in Spanish America: The Debate over Dueling, 1870-1920." Law and History Review 19, no. 2 (2001).

Phelan, John L. The people and the king. The Comunero Revolution in Colombia. Madison: University of Wisconsin Press, 1978.

Piccato, Pablo. "Conversación con los Difuntos: Una Perspectiva Mexicana ante el Debate sobre la Historia Cultural." Signos Históricos, no. 8 (2002): 13-41. - "'El populacho" y la opinión pública: Debates y motines sobre la deuda inglesa en 1884." In Poder y legitimidad en México, Siglo XIX: Instituciones y cultura política, edited by Brian Connaughton, 531-79. Mexico City: Universidad Autónoma Metropolitana-Miguel Angel Porrúa, 2003.

- "Introducción: ¿Modelo para armar? Hacia un acercamiento crítico a la teoría de la esfera pública." In Actores, espacios y debates en la historia de la esfera pública en la ciudad de México, edited by Cristina Sacristán and Pablo Piccato, 939. Mexico City: Instituto Mora, 2005.

. "Jurados de imprenta en México: El honor en la construcción de la esfera pública." In Construcciones impresas. Panfletos, diarios y revistas en la formación de los estados nacionales en América Latina, 1820-1920, edited by Paula Alonso, 139-65. Buenos Aires: FCE, 2004.

. "Politics and the Technology of Honor: Dueling in Turn-of-the-Century Mexico." Journal of Social History 33, no. 2 (1999): 331-54.

Pincus, Steve. ""Coffee Politicians Does Create": Coffeehouses and Restoration Political Culture." The Journal of Modern History 67, no. 4 (1995): 807-34.

Plotkin, Mariano Ben. Mañana es San Perón: A cultural history of Peron's Argentina, Latin American silhouettes. Wilmington, Del.: SR Books, 2003.

Portantiero, Juan Carlos. "Foundations of a New Politics." Report on the Americas 25, no. 5 (1991): 17-20.

Postone, Moishe. "Political Theory and Historical Analysis." In Habermas and the public sphere, edited by Craig Calhoun, 164-77. Cambridge, Mass.: MIT Press, 1992.

Purnell, Jennie. Popular Movements and State Formation in Revolutionary Mexico: The Agraristas and Cristeros of Michoacán. Durham: Duke University Press, 1999.

Putnam, Robert D. Bowling Alone: The Collapse and Revival of American Community. New York: Simon \& Schuster, 2000.

Rama, Angel. La novela en América Latina: Panoramas 1920-1980. Montevideo: Fundación Angel Rama Universidad Veracruzana, 1986.

_. La riesgosa navegación del escritor exiliado. Montevideo: Arca, 1993. 
. The Lettered City. Translated by John Charles Chasteen. Durham: Duke University Press, 1996.

Rama, Angel, and Rosario Peyrou. Diario, 1974-1983. Montevideo, Uruguay: Ediciones Trilce, 2001.

Ramos, Carmen, and et al. Presencia y transparencia: La mujer en la historia de México. Mexico City: El Colegio de México, 1987.

Rodríguez Kuri, Ariel. "Desabasto, hambre y respuesta política, 1915." In Instituciones y ciudad. Ocho estudios históricos sobre la ciudad de México, edited by Carlos Illades and Ariel Rodríguez Kuri, 133-64. Mexico City: FP-SONES-Uníos, 2000.

Rojas, Rafael. La escritura de la independencia: El surgimiento de la opinión pública en México. 1st ed. Mexico City: Taurus--Centro de Investigación y Docencia Económicas, 2003.

Romero, José Luis. Latinoamérica: las ciudades y las ideas. Buenos Aires: Siglo XXI, 1976.

Rubin, Jeffrey. Decentering the Regime: Ethnicity, Radicalism, and Democracy in Juchitán, Mexico. Durham: Duke University Press, 1997.

Ruiz Castañeda, María del Carmen, Luis Reed Torres, Enrique Cordero y Torres, and Salvador Novo. El periodismo en México: 450 años de historia. $<1$. ed.> ed. Mexico City: Editorial Tradición, 1974.

Sabato, Hilda. "Introducción: La vida política argentina: miradas históricas sobre el siglo XIX." In La vida política en la Argentina del siglo XIX: Armas, votos y voces, edited by Hilda Sabato and Alberto Rodolfo Lettieri, 335. Mexico City: Fondo de Cultura Económica, 2003.

_. "On Political Citizenship in Nineteenth-Century Latin America." American Historical Review 106, no. 4 (2001): 1290-326.

Sábato, Hilda. "Citizenship, Political Participation and the Formation of the Public Sphere in Buenos Aires 1850s-1880s." Past and Present, no. 136 (1992): 139-63. . Ciudadanía política y formación de las naciones: Perspectivas históricas de América Latina. Mexico City: Fondo de Cultura Económica, 1999.

_. La política en las calles : entre el voto y la movilización : Buenos Aires, 18621880. Buenos Aires: Editorial Sudamericana, 1998.

- The Many and the Few: Political Participation in Republican Buenos Aires. Stanford, Calif:: Stanford University Press, 2001.

Sábato, Hilda, Alberto Rodolfo Lettieri, and Programa de Estudios de Historia Económica y Social Americana., eds. La vida política en la Argentina del siglo $X I X$ : armas, votos y voces. 1a ed, Sección de obras de historia. México ; Estados Unidos de América ; Buenos Aires: Fondo de Cultura Económica, 2003.

Salvatore, Ricardo Donato, Carlos Aguirre, and Gilbert M. Joseph. Crime and Punishment in Latin America: Law and Society since Late Colonial Times. Durham <N.C.>: Duke University Press, 2001.

Sarkar, Sumit. "Orientalism Revisited: Saidian Frameworks in the Writing of Modern Indian History." In Mapping subaltern studies and the postcolonial, edited by Vinayak Chaturvedi, 239-55. London: Verso, 2000.

Scobie, James R. Buenos Aries, From Plaza to Suburb, 1870-1910. New York: Oxford University Press, 1974. 
Scott, James C. Domination and the Arts of Resistance: Hidden Transcripts. New Haven: Yale University Press, 1990.

Sennett, Richard. The Fall of Public Man. New York: Knopf, 1977.

Serulnikov, Sergio. "Disputed Images of Colonialism: Spanish Rule and Indian Subversion in Northern Potosi, 1777-1780." Hispanic American Historical Review 76, no. 2 (1996): 189-226.

Simmons, Charles E. P. . "Palafox and His Critics: Reappraising a Controversy." Hispanic American Historical Review 46, no. 4 (1966): 394-408.

Somers, Margaret R. "Narrating and Naturalizing Civil Society and Citizenship Theory: The Place of Political Culture and the Public Sphere." Sociological Theory 13, no. 3 (1995): 229-74.

Stern, Steve. "Between Tragedy and Promise: The Politics of Writing Latin American History in the Late Twentieth Century." In Reclaiming the political in Latin American history : essays from the North, edited by G. M. Joseph, 32-77. Durham, NC: Duke University Press, 2001.

Strum, Arthur. "A Bibliography on the Concept of Öffentlichkeit." New German Critique 61 (1994).

Taylor, William B. "Between Global Process and Local Knowledge: An Inquiry into Early Latin American Social History, 1500-1900." In Reliving the Past: The Worlds of Social History, edited by Olivier Zunz. Chapel Hill: University of North Carolina Press, 1985.

- Drinking, Homicide, and Rebellion in Colonial Mexican Villages. Stanford: Stanford University Press, 1989.

- Magistrates of the Sacred: Priests and Parishioners in Eighteenth-Century Mexico. Stanford, Calif.: Stanford University Press, 1996.

Thompson, E. P. The Making of the English Working Class. New York: Random House, 1966.

Thomson, Guy P. C., and David G. LaFrance. Patriotism, Politics, and Popular Liberalism in Nineteenth-Century Mexico: Juan Francisco Lucas and the Puebla Sierra, Latin American silhouettes. Wilmington, Del.: Scholarly Resources, 1999.

Thomson, Sinclair. We Alone Will Rule: Native Andean Politics in the Age of Insurgency, Living in Latin America. Madison: University of Wisconsin Press, 2002.

Thorne, Christian. "Thumbing Our Nose at the Public Sphere: Satire, the Market, and the Invention of Literature." Publications of the Modern Language Association of America 116, no. 3 (2001): 531-44.

Thurner, Mark. "'Republicanos' and 'La Comunidad de Peruanos': Unimagined Political Communities in Postcolonial Andean Peru." Journal of Latin American Studies 27, no. 2 (1995).

Toussaint Alcaraz, Florence. Escenario de la prensa en el Porfiriato. 1. ed. ed. Mexico City: Fundacion Manuel Buendía-Universidad de Colima, 1989.

Tutino, John. From Insurrection to Revolution in Mexico: Social Bases of Agrarian Violence, 1750-1940. Princeton: Princeton University Press, 1988.

Twinam, Ann. Public Lives, Private Secrets: Gender, Honor, Sexuality, and Illegitimacy in Colonial Spanish America. Stanford, Calif.: Stanford University Press, 1999. 
Uribe Uran, Victor. "The Birth of a Public Sphere in Latin America during the Age of Revolution." Comparative Studies in Society and History 42, no. 2 (2000): 42557.

- State and Society in Spanish America during the Age of Revolution, Latin American silhouettes. Wilmington, Del.: Scholarly Resources, 2001.

Van Young, Eric. "Conclusions." In State and Society in Spanish America during the Age of Revolution, edited by Victor Uribe Uran. Wilmington, Del.: Scholarly Resources, 2001.

- The Other Rebellion: Popular Violence, Ideology, and the Mexican Struggle for Independence, 1810-1821. Stanford, Calif:: Stanford University Press, 2001.

Vaughan, Mary Kay. Cultural Politics in Revolution: Teachers, Peasants, and Schools in Mexico, 1930-1940. Tucson: University of Arizona Press, 1997.

Viotti da Costa, Emilia. "Experience versus Structures: New Tendencies in the History of Labor and the Working Class in Latin America--What Do We Gain? What Do We Lose?" International Labor and Working-Class History 36 (1989): 3-24.

Walker, Charles. Smoldering ashes : Cuzco and the creation of Republican Peru, 17801840, Latin America otherwise. Durham, NC: Duke University Press, 1999.

Warner, Michael. The letters of the Republic: Publication and the Public Sphere in Eighteenth-Century America. Cambridge, Mass.: Harvard University Press, 1990.

-. Publics and Counterpublics. New York, Cambridge, Mass.: Zone Books Distributed by MIT Press, 2002.

Warren, Richard A. Vagrants and citizens : politics and the masses in Mexico City from Colony to Republic, Latin American silhouettes. Wilmington, Del.: SR Books, 2001.

Winn, Peter. Weavers of revolution. The Yarur workers and Chile's road to socialism. New York: Oxford University Press, 1986.

Wolfe, Joel. Working Women, Working Men: Sao Paulo and the Rise of Brazil's Industrial Working Class, 1900-1955. Durham: Duke University Press, 1993. 